https://doi.org/10.5194/bg-2021-157

Preprint. Discussion started: 8 July 2021

(C) Author(s) 2021. CC BY 4.0 License.

(c) (i)

\title{
Quantification of Blue Carbon in Salt Marshes of the Pacific Coast of Canada
}

\author{
Stephen G. Chastain ${ }^{1}$, Karen Kohfeld ${ }^{1,2}$, Marlow G. Pellatt ${ }^{1,3}$, Carolina Olid ${ }^{4}$, Maija Gailis ${ }^{5}$
}

${ }^{1}$ School of Resource \& Environmental Management, Simon Fraser University, Burnaby, Canada V5A 1S6. Coast Salish

5 Territories, $\mathrm{x}^{\mathrm{w}} \mathrm{m} ə \theta \mathrm{k}^{\mathrm{w}}$ əy่əm (Musqueam), Skwxwú7mesh (Squamish) \& səlilwətaP1 (Tsleil-Waututh)

${ }^{2}$ School of Environmental Science, Simon Fraser University, Burnaby, Canada, V5A 1S6

${ }^{3}$ Parks Canada, Protected Areas Establishment and Conservation Directorate, Vancouver, British Columbia, Canada V6B 6B4

${ }^{4}$ Department of Forest Ecology and Management, Swedish University of Agricultural Science, Umeå, Sweden

$10{ }^{5}$ Environment and Climate Change Canada, Climate Change Branch, Ottawa, Ontario, Canada

Correspondence to: Karen E Kohfeld (kohfeld@sfu.ca) 
https://doi.org/10.5194/bg-2021-157

Preprint. Discussion started: 8 July 2021

(c) Author(s) 2021. CC BY 4.0 License.

Abstract. Tidal salt marshes are known to accumulate "blue carbon" at high rates relative to their surface area, which render these systems among the Earth's most efficient carbon (C) sinks. However, the potential for tidal salt marshes to mitigate

15 global warming remains poorly constrained because of the lack of representative sampling of tidal marshes from around the globe, inadequate areal extent estimations, and inappropriate dating methods for accurately estimating $\mathrm{C}$ accumulation rates. Here we provide the first estimates of organic $\mathrm{C}$ storage and accumulation rates in salt marshes along the Pacific Coast of Canada, within the Clayoquot Sound UNESCO Biosphere Reserve and Pacific Rim National Park Reserve, a region currently underrepresented in global compilations. Within the context of other sites from the Pacific Coast of North America,

20 these young Clayoquot Sound marshes have relatively low $\mathrm{C}$ stocks but are accumulating $\mathrm{C}$ at rates that are higher than the global average, with pronounced differences between high and low marsh habitats. The average $\mathrm{C}$ stock calculated during the past 30 years is $54 \pm 5 \mathrm{Mg} \mathrm{C} \mathrm{ha}^{-1}$ (mean \pm standard error), which accounts for $81 \%$ of the $\mathrm{C}$ accumulated to the base of the marsh peat layer $\left(67 \pm 9 \mathrm{Mg} \mathrm{C} \mathrm{ha}^{-1}\right)$. The total $\mathrm{C}$ stock is just under one-third of previous global estimates of salt marsh $\mathrm{C}$ stocks, likely due to the shallow depth and young age of the marsh. In contrast, the average C accumulation rate (CAR) (184

$25 \pm 50 \mathrm{~g} \mathrm{C} \mathrm{m}^{-2} \mathrm{yr}^{-1}$ to the base of the peat layer) is higher than both CARs from salt marshes along the Pacific coast (112 \pm 12 $\left.\mathrm{g} \mathrm{C} \mathrm{m}^{-2} \mathrm{yr}^{-1}\right)$ and global estimates $\left(91 \pm 7 \mathrm{~g} \mathrm{C} \mathrm{m}^{-2} \mathrm{yr}^{-1}\right)$. This difference was even more pronounced when we considered individual marsh zones: CARs were significantly greater in high marsh $\left(303 \pm 45 \mathrm{~g} \mathrm{C} \mathrm{m}^{-2} \mathrm{yr}^{-1}\right)$ compared to the low marsh sediments $\left(63 \pm 6 \mathrm{~g} \mathrm{C} \mathrm{m}^{-2} \mathrm{yr}^{-1}\right)$, an observation unique to Clayoquot Sound among NE Pacific Coast marsh studies. We attribute low CARs in the low marsh zones to shallow-rooting vegetation, reduced terrestrial sediment inputs, negative

30 relative sea level rise in the region, and enhanced erosional processes. Per-hectare, CARs in Clayoquot Sound marsh soils are approximately 2-7 times greater than $\mathrm{C}$ uptake rates based on net ecosystem productivity in Canadian boreal forests, which highlights their potential importance as $\mathrm{C}$ reservoirs and the need to consider their $\mathrm{C}$ accumulation capacity as a climate mitigation co-benefit when conserving for other salt marsh ecosystem services.

\section{Introduction}

35 Coastal, vegetated ecosystems, such as seagrass meadows, mangroves, and tidal salt marshes, have recently been recognized for their ability to store large amounts of "blue carbon" within their soils and sediments (IPCC 2014; Howard et al. 2014). While blue carbon ecosystems cover approximately $0.2 \%$ of the ocean surface, they have been estimated to be responsible for up to $50 \%$ of total coastal ocean carbon (C) burial (including estuaries and continental platforms) (Duarte et al. 2005), and their per-area $\mathrm{C}$ sequestration rate is substantially greater than that of terrestrial forest soils (McLeod et al. 2011).

40 Globally, blue $\mathrm{C}$ ecosystems have been estimated to sequester between 75 and $224 \mathrm{Tg} \mathrm{C}^{-1}$ (Duarte et al. 2013). For comparison, deep ocean organic carbon burial rates were recently estimated to be $20 \pm 6 \mathrm{Tg} \mathrm{C}^{-1}$ (Hayes et al. 2021), with an additional burial of $222 \mathrm{Tg} \mathrm{C} \mathrm{yr}^{-1}$ estimated for shelves and platforms shallower than $1000 \mathrm{~m}$ (Burdige, 2007). Due to this high $\mathrm{C}$ storage and accumulation rate capacity per unit area, coastal vegetated ecosystems have been suggested to play an important role in climate warming mitigation (Howard et al. 2017). However, when the ecosystem is degraded, the stored C

45 can be released, and annual C uptake by the ecosystem ceases, resulting in losses of ecosystem services (McLeod et al. 2011, Pendleton et al 2012). Thus, to better inform policies that identify priority areas for conservation, more precise measurement of C stocks and accumulation potential are needed (Howard et al. 2017).

Global estimates of salt marsh area, C stocks, and C accumulation rates (CAR) are subject to large uncertainties. Duarte et al. (2013) noted a 20-fold uncertainty in global estimates of salt marsh area (ranging from 22,000-to 400,000 km²) associated

50 with ambiguous classification schemes for wetlands. For example, some classification systems consider freshwater and saltwater marshes in the same category (Duarte et al. 2013). Similarly, the estimated, global soil C stock of all salt marshes 
https://doi.org/10.5194/bg-2021-157

Preprint. Discussion started: 8 July 2021

(c) Author(s) 2021. CC BY 4.0 License.

ranges between 0.4 and 6.5 Pg C, a 16-fold range (Duarte et al. 2013). The average global CAR for salt marshes was estimated as $91 \pm 19 \mathrm{~g} \mathrm{C} \mathrm{m}^{-2} \mathrm{yr}^{-1}$ by the Intergovernmental Panel on Climate Change (IPCC, 2013 ) and then as $245 \pm 26 \mathrm{~g} \mathrm{C}$ $\mathrm{m}^{-2} \mathrm{yr}^{-1}$ in a subsequent global compilation (mean \pm standard deviation) (Ouyang and Lee 2014). Furthermore, these reviews of salt marsh CAR estimates note disproportionate representation from certain areas of the world (Ouyang and Lee 2014; Chmura et al. 2003). Some areas, such as Europe and eastern North America, have dozens of CAR data points, while others, such as western North America, East Asia, and Australia are underrepresented. Regions such as Africa, India, and South America have fewer or no data at all. The high variability in CAR from site to site combined with the 20 -fold uncertainty in global marsh area estimates result in global salt marsh CAR estimates ranging from 0.9 to $31.4 \mathrm{Tg} \mathrm{C}^{-1}$ (Ouyang and Lee

60 2014). This 35-fold range is seven times greater than the global range for mangroves (Ouyang and Lee 2014; Donato et al. 2011).

The extensive use of ${ }^{137} \mathrm{Cs}$ radioisotope or a marker horizon method for sediment dating also limits comparisons of CAR between studies. The difficulties of quantifying low concentrations of ${ }^{137} \mathrm{Cs}$ in coastal sediments, and its low retention in high organic content sediments (Davis et al. 1984), limits the applicability of this technique to estimate CAR in salt marshes and leads to overestimates of sediment accumulation rates when compared to other dating methods such as ${ }^{210} \mathrm{~Pb}$ dating (e.g. Callaway et al. 2012; Johannessen and MacDonald 2016). Unlike ${ }^{137} \mathrm{Cs}$, the natural radionuclide ${ }^{210} \mathrm{~Pb}$ is highly retained in organic matter, which makes it suitable for establishing the chronology of sedimentary deposits accumulated over approximately the past 100 years (Krishnaswamy et al. 1971; Arias-Ortiz et al. 2018). Also, the lower detection limits of ${ }^{210} \mathrm{~Pb}$ reduce analytical errors in the derived chronologies below those obtained by using ${ }^{137} \mathrm{Cs}$ providing, thus, better 70 constrained recent CAR for salt marshes (e.g., Corbett and Walsh, 2015).

The Commission for Environmental Cooperation (CEC), a tri-national governmental organization promoting scientific cooperation between Canada, the United States, and Mexico, identified the Pacific coast of Canada as a significant data gap in terms of our knowledge of the aerial extent and quantification of blue $\mathrm{C}$ storage and accumulation. Additionally, a review of global salt marsh CAR data identified only eight sites on the entire Pacific coast of the continent, none of which were north of $38.2^{\circ} \mathrm{N}$ (Ouyang and Lee 2014). This study aims to address this data gap by providing C stock and CAR from the Pacific Coast of Canada as a part of the Government of Canada's contribution to a continent-wide assessment of blue C mitigation potential. We sampled seven salt marshes within the United Nations Educational, Scientific, and Cultural Organization (UNESCO) Clayoquot Sound Biosphere Reserve, British Columbia's Tofino Mudflats Wildlife Management Area, and Pacific Rim National Park Reserve of Canada on Vancouver Island, British Columbia (Fig. 1). These mesotidal

80 estuarine marshes, often constrained in size by surrounding topography, are typical of the marshes found on the Pacific coast of British Columbia, and therefore provide a good representation of many of the tidal wetland ecosystems found here (Ryder et al. 2007). We calculated soil $\mathrm{C}$ stocks (per unit area) across the high and low marsh zones of each marsh and used ${ }^{210} \mathrm{~Pb}$ dating in a subset of the collected cores to quantify CAR. We then used the extent of high and low marsh areas from aerial imagery to estimate total $\mathrm{C}$ storage and total annual $\mathrm{C}$ accumulation. Finally, we place these new data within the context of 85 CAR estimates from salt marshes in the NE Pacific region. 

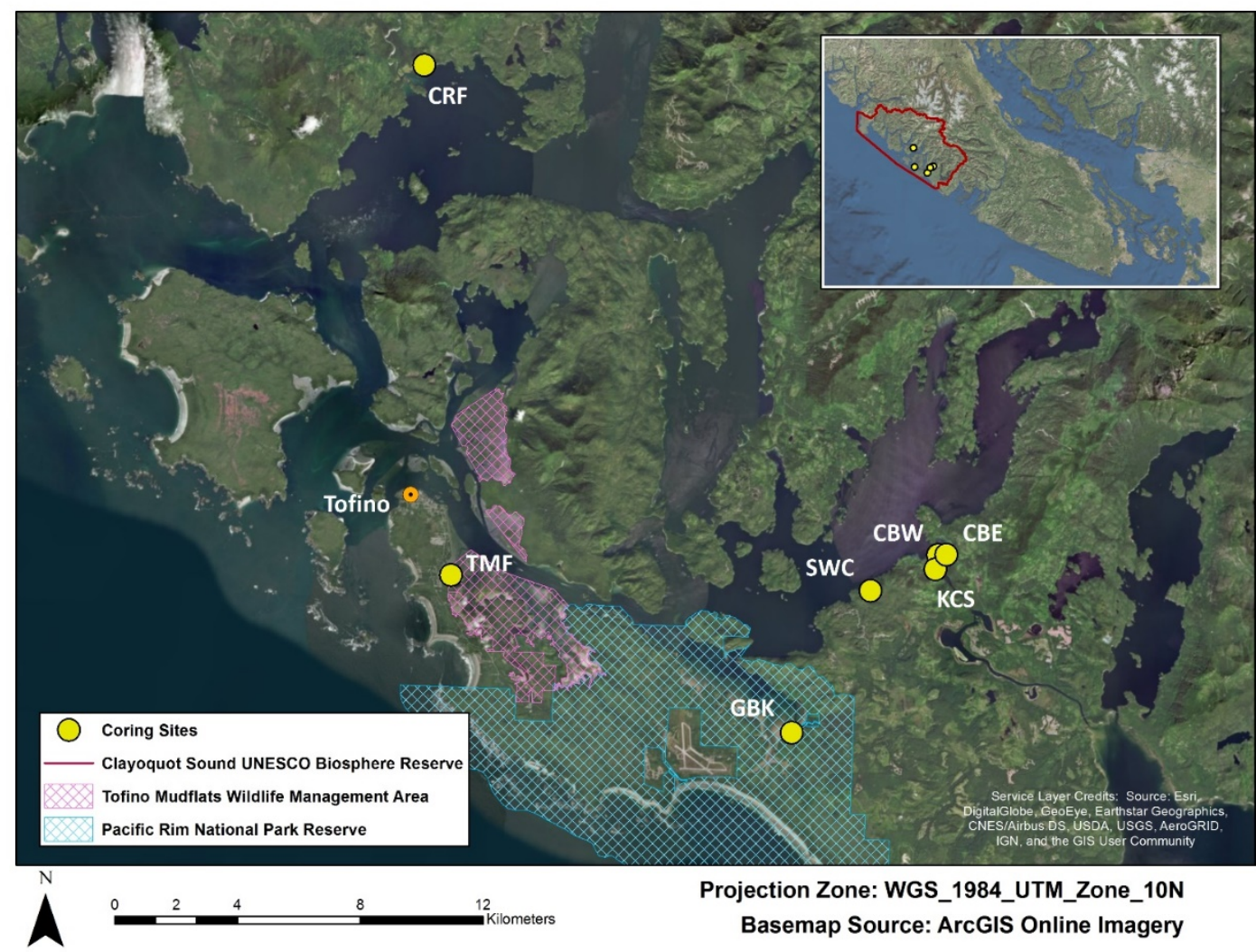

Projection Zone: WGS_1984_UTM_Zone_10N

Basemap Source: ArcGIS Online Imagery

Figure 1. Site locations. Cypress River Flats (CRF), Cannery Bay East (CBE), Cannery Bay West (CBW), Kennedy Cove South (KCS), Shipwreck Cove (SWC), Grice Bay at Kootowis Creek (GBK), and Tofino Mudflats (TMF). Pacific Rim National Park and Reserve (blue crosshatching) covers the southern portion of the map and the Tofino Mudflats Wildlife Management Area (pink 90 crosshatching) covers portions of the southwestern area. The study region lies within the Clayoquot Sound UNESCO Biosphere Reserve, British Columbia, Canada (inset, outlined).

\section{Methods}

\subsection{Study Area}

95 Clayoquot Sound is a complex system of inlets on the west coast of Vancouver Island, British Columbia, Canada. The sparsely-populated area includes several protected area designations, including the Long Beach Unit of Pacific Rim National Park and Reserve of Canada, the Province of British Columbia's Tofino Mudflats Wildlife Management Area, and the UNESCO Clayoquot Sound Biosphere Reserve, which protects 366,000 hectares of the west coast of Vancouver Island (Fig.

1). The region is part of the temperate rainforest biome with high annual rainfall (3270 mm $\left.\mathrm{y}^{-1}\right)$ and average annual 
https://doi.org/10.5194/bg-2021-157

Preprint. Discussion started: 8 July 2021

(c) Author(s) 2021. CC BY 4.0 License.

(c) (i)

100 temperature of $9.5{ }^{\circ} \mathrm{C}$ (Environment Canada, 1981-2010 averages for Tofino). The mean tidal range in Tofino is $2.14 \mathrm{~m}$ (Fisheries and Oceans 2016).

These sites are typical of salt marshes along Canada's Pacific coast because they include small, pocket marshes encompassing an enclosed, semi-circular area of coastline as well as larger, estuarine marshes. Surface water salinity ranged from 5.9 at KCS to 24 in Grice Bay, and 29 at Roberts Point six km south of CRF (Postlethwaite et al. 2018).

\subsection{Field Sampling}

Within each marsh $(n=7)$, vegetation composition was noted in $50 \times 50 \mathrm{~cm}$ quadrats before sediment cores $(n=34)$ were extracted during summer 2016 along linear transects perpendicular to the low tide shoreline, following the methodology of Howard et al. (2014). Coring spots were approximately evenly spaced along the transect (between 9 and 24 meters apart) from land to sea and spanned the low and high marsh zones. Core locations were chosen to avoid ditches and channels

110 without organic soil accumulation; these ditches and channels made up a relatively small portion of total marsh surface area $(<5 \%)$.

Vegetation composition was recorded as an indicator of 'low' vs 'high' marsh zones (Porter 1982; Weinmann et al. 1984) around each coring spot. Coring spots were considered low marsh if the species Triglochin maritima, Salicornia spp., Fucus ssp. or Ditschilis spicata were present, and high marsh if it included Plantago maritima, Deschampsia caespitosa, Grindelia

115 integrifolia, Potentilla anserina, Glaux maritima, or Eleocharis ssp. If a spot contained a mixture of these species, the majority percent cover of high or low marsh species was used to determine whether the spot was high or low marsh. Carex lyngbyei were often found throughout both strata and so were not considered unique to one zone. The high marsh species' ranges align approximately with the mean extreme high-water line of estuarine marshes in Clayoquot Sound, while low marsh encompasses elevations between the mean lower high water and the mean extreme high-water lines (Jefferson 1973 as

120 cited in Deur 2000; Weinmann et al. 1984). This method was verified using detrended correspondence analysis, which showed that vegetation assemblages reflected distinct low and high marsh zones (Hill and Gauch 1980; Appendix B).

Sediment cores were collected using a simple percussion coring technique in which a length of two-inch (57 mm) diameter, PVC vacuum tubing fitted with a plastic core catcher (AMS Inc.) was hammered into the ground until the depth of refusal (DoR). The DoR was reached between depths of 7 and $62 \mathrm{~cm}$. In 19 of the 34 cores, the DoR was reached when the corer

125 penetrated approximately $5-15 \mathrm{~cm}$ into layers of sand or gravel at the base of the marshes (see Supplemental Information, Table A2). A similar layer is reached in the eelgrass meadows that form seaward of these marshes (Postlethwaite et al., 2018). At these locations, our cores were able to sample the depth of initiation of marsh-related organic $\mathrm{C}$ accumulation. At eight of the 34 locations, the cores reached depths where peat mixed substantially with sand or clay; the remaining seven cores ended in peat layers. With three exceptions, the DoR occurred at minimum \%C.

130 At one site (GBK) a steel sledge corer (AMS Inc.) was used to extract four cores, but mechanical problems required switching to the simpler method described above. These four cores penetrated approximately $15-30 \mathrm{~cm}$ into the sand/gravel layer below the marsh, which contained minimal amounts of C. Marsh characteristics (e.g. average percent carbon, dry bulk 
https://doi.org/10.5194/bg-2021-157

Preprint. Discussion started: 8 July 2021

(c) Author(s) 2021. CC BY 4.0 License.

(c) (i)

density, soil $\mathrm{C}$ density, $\mathrm{C}$ stocks, and $\mathrm{C}$ accumulation rates) were determined by considering only the upper part of the profile containing peat and overlying sand, gravel, or clay, and these cores were excluded from our average estimates of the DoR.

All cores were stored upright until their return to the laboratory where they were photographed, logged, and stored under refrigeration at a Parks Canada laboratory in Vancouver, British Columbia.

\subsection{Marsh Area Estimations}

140 ArcMap 10.3 tools were used with 50 × $50 \mathrm{~cm}$ resolution aerial orthophotos taken in July 2014 (Government of British Columbia) to estimate the area of high and low marsh zones. The difference between high marsh and low marsh was delineated by eye between darker-green, denser high marsh vegetation and lighter-green, salt-tolerant, and less-dense low marsh vegetation. This method was verified using the detrended correspondence analysis (e.g. Hill and Gauch 1980) of vegetation survey data and was found to accurately categorize $94 \%$ of the cores into the correct marsh zone (see

145 Supplemental Information, Appendix B). Similar approaches in Boundary Bay marsh in BC, Canada have resulted in a high degree of correspondence between marsh color and low vs high marsh delineation (Gailis et al., 2021).

\subsection{Soil Carbon Content}

Organic $\mathrm{C}$ content $\left(\% \mathrm{C}=\mathrm{g} \mathrm{C} \mathrm{g}^{-1}\right.$ marsh sediment) was determined using loss-on-ignition (\%LOI) validated with $\mathrm{CN}$ Elemental and coulometric analysis (Froelich 1980). LOI analysis was performed on every $1 \mathrm{~cm}$ subsample by

150 homogenizing samples with a mortar and pestle, combusting them at $550^{\circ} \mathrm{C}$ for four hours, weighing, and combusting again at $1000^{\circ} \mathrm{C}$ for two hours (Heiri et al. 2001). The percentage mass loss-on-ignition (\%LOI) was estimated as:

$\% L O I=\frac{D W i-D W f}{D W i} \times 100$

where $D W_{i}$ is initial dry weight $[\mathrm{g}]$ and $D W_{f}$ is the dry weight $[\mathrm{g}]$ after burning. For comparison, the $\% \mathrm{C}$ was also estimated by measuring total $\mathrm{C}(\% \mathrm{TC})$ and inorganic $\mathrm{C}(\% \mathrm{IC})$ on a subset of 93 samples (see supplemental data). \%TC was measured on these homogenized subsamples using dry combustion elemental analysis with an Elementar Elemental Analyzer for CN analysis at the University of British Columbia's Department of Earth, Ocean, and Atmospheric Sciences. The same subsamples were then analyzed for \% IC using a UIC CM5014 $\mathrm{CO}_{2}$ coulometer connected to a UIC CM5130 acidification module in the Climate, Oceans, and Paleo-Environments (COPE) laboratory at Simon Fraser University. Measurements of \%IC were subtracted from the \%TC measurements to estimate \%C (Hodgson and Spooner 2016; Hedges and Stern 1984; Schumacher 2002; Howard et al. 2014). Inorganic C was negligible in all 93 of the subsamples analysed (max: $0.015 \%$ ) and assumed to be zero for all $\mathrm{C}$ calculation purposes. The strong correlation $\left(\mathrm{R}^{2}=0.96, \mathrm{p}<0.05\right)$ observed between $\% \mathrm{LOI}$ and $\% \mathrm{C}$ for this set of samples allowed us to use this relationship to convert $\% \mathrm{LOI}$ to $\% \mathrm{C}$ for all samples using: 
https://doi.org/10.5194/bg-2021-157

Preprint. Discussion started: 8 July 2021

(c) Author(s) 2021. CC BY 4.0 License.

(c) (i)

$\% C=0.44(\% L O I)-1.80$

Soil $\mathrm{C}$ density ( $\mathrm{SCD}\left[\mathrm{g} \mathrm{C} \mathrm{cm}^{-3}\right]$ ) was obtained as the product of the $\mathrm{C}$ content and the dry bulk density $\left(\mathrm{DBD}\left[\mathrm{g} \mathrm{C} \mathrm{cm}^{-3}\right]\right)$ :

$165 S C D\left(\frac{g C}{c m^{3}}\right)=\left(\frac{\% C}{100}\right) \times D B D$

where DBD was estimated after drying the sediment for no less than 72 hours at $60^{\circ} \mathrm{C}$. Specifically, DBD was measured by bisecting the core while still inside its casing with a clean, serrated knife to avoid cross-contamination or inaccurate volume measurement that might be caused by extruding the core. Volume was precisely measured immediately afterward using a custom-designed, brass implement designed to remove a single cubic centimeter of soil at a time from the flat face of the bisected core.

\subsection{Marsh profiles chronology}

The naturally-occurring radionuclide ${ }^{210} \mathrm{~Pb}$ was analysed in sediment from a subset of eight cores to determine recent $\mathrm{C}$ accumulation rates (CARs) (Appleby et al. 1992). One high marsh and low marsh core, each, from CBE, CRF, GBK, and TMF were chosen to represent the two marsh zones in various sites of different sizes. A set of subsamples ( $\mathrm{n}=6-7$ for cores shorter than $20 \mathrm{~cm}, \mathrm{n}=11-17$ for longer cores) was sent to Core Scientific International (Winnipeg, Canada), Flett Research (Winnipeg, Canada), and MyCore Scientific (Dunrobin, Canada) to determine ${ }^{210} \mathrm{~Pb}$ content. Activities of ${ }^{210} \mathrm{~Pb}$ were determined by $\alpha$-spectrometry through its granddaughter ${ }^{210} \mathrm{Po}$, assumed in secular equilibrium. The atmospheric or excess ${ }^{210} \mathrm{~Pb}\left({ }^{210} \mathrm{~Pb}_{\mathrm{xs}}\right)$ fraction used to derive the age-depth model was determined as the difference between the total ${ }^{210} \mathrm{~Pb}$ activity and its parent nuclide ${ }^{226} \mathrm{Ra}$ activity (Table A2). ${ }^{226} \mathrm{Ra}$ activities were determined by $\alpha$-spectrometry at Flett Research using calibrated geometries in a glass vessel, Spectech UCS 30 Alpha Scintillation Spectrometer purged with helium, and sealed for at least 11 days (Mathieu et al. 1988). Samples were sealed and stored for two hours before counting to ensure secular equilibrium of ${ }^{226} \mathrm{Ra}$ daughters. ${ }^{226} \mathrm{Ra}$ was determined through counting ${ }^{222} \mathrm{Rn}$ activity for 60,000 seconds (Minimum Detectable Activity $\left.(\mathrm{MDA})=0.0167 \mathrm{~Bq} \mathrm{~kg}^{-1}\right)$.

Because most of the cores did not show complete excess ${ }^{210} \mathrm{~Pb}$ profile (see Results), sediment chronologies were estimated using the Constant Flux: Constant Sedimentation (CF:CS) model (Khrishnaswamy et al. 1971; Equation 4), which assumes a constant atmospheric deposition of ${ }^{210} \mathrm{~Pb}$ to the marsh surface and a constant mass accumulation rate (MAR, [g cm$\left.{ }^{-2} \mathrm{yr}^{-1}\right]$ ). Under these assumptions, the MAR can be obtained from the slope $\left[\mathrm{cm}^{2} \mathrm{~g}^{-1}\right]$ of the linear best-fit line of the relationship between the natural $\log$ of the excess ${ }^{210} \mathrm{~Pb}$ activity against the cumulative mass $\left[\mathrm{g} \mathrm{cm}^{-2}\right]$ using:

$\operatorname{MAR}\left(\mathrm{g} \mathrm{cm}^{-2} \mathrm{yr}^{-1}\right)=\frac{0.0311\left(\mathrm{yr}^{-1}\right)}{\text { slope }\left(\mathrm{cm}^{2} \mathrm{~g}^{-1}\right)}$

190 where $0.0311 \mathrm{yr}^{-1}$ is the radioactive decay constant of ${ }^{210} \mathrm{~Pb}$. 
https://doi.org/10.5194/bg-2021-157

Preprint. Discussion started: 8 July 2021

(c) Author(s) 2021. CC BY 4.0 License.

(c) (i)

\subsection{Carbon stocks}

Organic $\mathrm{C}$ stocks $\left[\mathrm{g} \mathrm{cm}^{-2}\right]$ are used as a proxy for total organic $\mathrm{C}$ storage in marshes and are calculated by integrating all peat layers $(n)$ of the profile $[\mathrm{cm}]$ :

C stock $\left(\mathrm{gC} \mathrm{cm}^{-2}\right)=\sum_{i=0}^{n} S C D_{i} \times 1 \mathrm{~cm}$

195 As most cores penetrated to a sand or gravel layer found at the base of the marsh (see Sect. 2.2), we are confident that the estimated C stocks ("based of peat C stocks", hereafter) capture all marsh-associated C emplaced since the formation of the marsh. Because $\mathrm{C}$ stocks are estimated directly from sediment cores and not from the overall depth of marsh soils, correction of core compaction was not necessary.

To facilitate comparison with other studies, we also report the mean $\mathrm{C}$ stock $\left(\mathrm{Mg} \mathrm{C}^{-1}\right)$ to a depth of $20 \mathrm{~cm}$ for the region 200 (20-cm C stocks, hereafter). Here we estimated the accumulated C to the corrected (uncompacted) depth of $20 \mathrm{~cm}$ in each core, with the caveat that 3 of the 34 cores did not reach a depth of $20 \mathrm{~cm}$ and therefore were not included in this calculation (Table A1).

Measurements of $\mathrm{C}$ stocks based on the accumulation of organic $\mathrm{C}$ up to certain depth, however, might give an incorrect impression of $\mathrm{C}$ sequestration capacity when comparing sites with different accumulation rates. The dating of the cores,

205 however, allows one to circumvent this problem by normalizing $\mathrm{C}$ stocks to a certain age horizon. We therefore used a horizon of 30 years before time of sampling to calculate these stocks (hereafter 30-year C stock). We chose this age-depth horizon because it represented the oldest ${ }^{210} \mathrm{~Pb}$ date shared between the eight dated cores.

Finally, we estimated the total $\mathrm{C}$ storage $(\mathrm{Mg} \mathrm{C})$, in each marsh and for all seven marshes combined, by multiplying the average $\mathrm{C}$ stocks by the aerial extent of each marsh (Table 1). The total $\mathrm{C}$ storage was also estimated for low marsh and high marsh areas separately $(\mathrm{Mg} \mathrm{C})$. These estimates were made both to the depth of the base of the deepest peat (base of peat) layer and for the 20 -cm horizon carbon stock estimates. Note that total $\mathrm{C}$ storage was not estimated for the 30 -years horizon because we only had ages in four of the seven marshes, and thus there were three marshes where $\mathrm{C}$ storage could not be estimated to 30 years.

\subsection{Carbon Accumulation Rates}

215 We calculated C accumulation rates (CARs) in two ways: (1) to the "base of peat" depth of the deepest peat-containing layer overlying sand, gravel, or clay, and (2) to the greatest, common age horizon shared by all cores to allow comparisons between cores over equivalent timespans (30 years), which we call the "30-year CAR.". We include the whole core CAR calculation to assess any potential bias in the results due to higher overall $\mathrm{C}$ content in more recent accumulation and for easier comparison with other studies. This organic $\mathrm{C}$ fraction is calculated as:

$220 \% C=\frac{\sum_{t=0}^{t=i y r s} C\left(\mathrm{~g} \mathrm{~cm}^{2}\right)}{\sum_{t=0}^{t=i y r s} m\left(\mathrm{~g} \mathrm{~cm}^{2}\right)}$ 
https://doi.org/10.5194/bg-2021-157

Preprint. Discussion started: 8 July 2021

(c) Author(s) 2021. CC BY 4.0 License.

(c) (i)

where $i$ is either 30 years or the oldest peat-containing layer with detectable excess ${ }^{210} \mathrm{~Pb}$ activity for the core. The CAR is the product of this $\% \mathrm{C}$ and the MAR from Eq. 4 :

$\operatorname{CAR}\left(\mathrm{gC} \mathrm{cm}^{2} \mathrm{yr}^{-1}\right)=\% C_{\text {core }} \cdot \operatorname{MAR}\left(\mathrm{g} \mathrm{cm}^{-2} \mathrm{yr}^{-1}\right)$

Average CARs were calculated for the high marsh, the low marsh, and the entire region, using the eight cores with ${ }^{210} \mathrm{~Pb}$

225 dating, both for the whole cores as well as to the 30-year horizon (Table 2). Marsh-wide $\mathrm{C}$ accumulation rates $C$ Accumulation were calculated by multiplying CAR by the marsh area, for the high marsh, low marsh, and then for the full marsh (Table 2):

C Accumulation $\left(g C y r^{-1}\right)=\left[C A R_{\text {high marsh }}\left(g C m^{-2} y r^{-1}\right) \times \operatorname{area}_{\text {high marsh }}\left(m^{2}\right)+C A R_{\text {low marsh }}\left(g_{C m^{-2}} y r^{-1}\right) \times\right.$ $\left.\operatorname{area}_{\text {low } \operatorname{marsh}}\left(m^{2}\right)\right]$

230 Marsh-wide annual carbon accumulation was also estimated for the whole study area, by multiplying the average CARs (high marsh, low marsh, and total) by the area of the seven marshes (Table 2).

\subsection{Statistical Analysis}

We use a simple t-test to test for significant differences in marsh characteristics (depth of peat base, carbon content, DBD, and SCDs), C stocks, and CARs between high and low marsh zones. We also compare base of peat C stocks, 20-cm C stocks, $30-\mathrm{yr} \mathrm{C}$ stocks, as well as for CARs estimated to 30 years and to the base of peat layer.

\section{Results}

\subsection{Soil Properties}

With a few exceptions, marsh soils in Clayoquot Sound consisted of three layers separated by defined horizons: topsoil, peat, and sand/clay layers (See Supplemental Information, Tables A2 and A3, Fig. A1). In all cores, organic C concentrations 240 were highest in the surface layers (10-45\%) and decreased to lowest values ( $\sim 0 \%)$ in the deepest parts of the cores (Fig. 2). Depths of refusal in the 34 cores ranged from $7 \mathrm{~cm}$ in a low marsh core of CBW to a maximum of $62 \mathrm{~cm}$ at CBE. The average ( \pm standard error (SE)) corrected depth of the deepest peat layer overlying a sand, gravel, or clay was $29 \pm 3 \mathrm{~cm}$ for the high marsh sites and $17 \pm 3 \mathrm{~cm}$ for the low marsh sites, with an overall average base of peat depth of $23 \pm 2 \mathrm{~cm}$ (Fig. 3a). Differences in the deepest peat layer depths were statistically significant between the high and low marsh zones (p-value $<$

245 0.05). We note, however, that the 10 cores which did not penetrate into the sand, clay, or gravel layer were not used in these calculations.

While the average base of peat depth of high marsh cores is significantly higher than that of low marsh cores, no significant differences were found for average DBD, average \% C, or average SCD ( $p>0.05)$ (Fig. 3b-d). Carbon contents averaged 21 $\pm 2 \%$ in the high marsh and $18.5 \pm 2 \%$ in the low marsh cores and $20 \pm 1 \%$ overall (Fig. 3b) and did not vary significantly 
https://doi.org/10.5194/bg-2021-157

Preprint. Discussion started: 8 July 2021

(c) Author(s) 2021. CC BY 4.0 License.

(c) (1)

250 between the high and low marsh zones. DBDs and SCDs also showed similar average values and distributions in the high and low marsh cores (Fig. 3c and 3d). When corrected for compaction, soil carbon densities averaged $0.027 \pm 0.002 \mathrm{~g} \mathrm{C} \mathrm{cm}^{-3}$ for all sites and ranged from 0.008 to $0.067 \mathrm{~g} \mathrm{C} \mathrm{cm}^{-3}$.

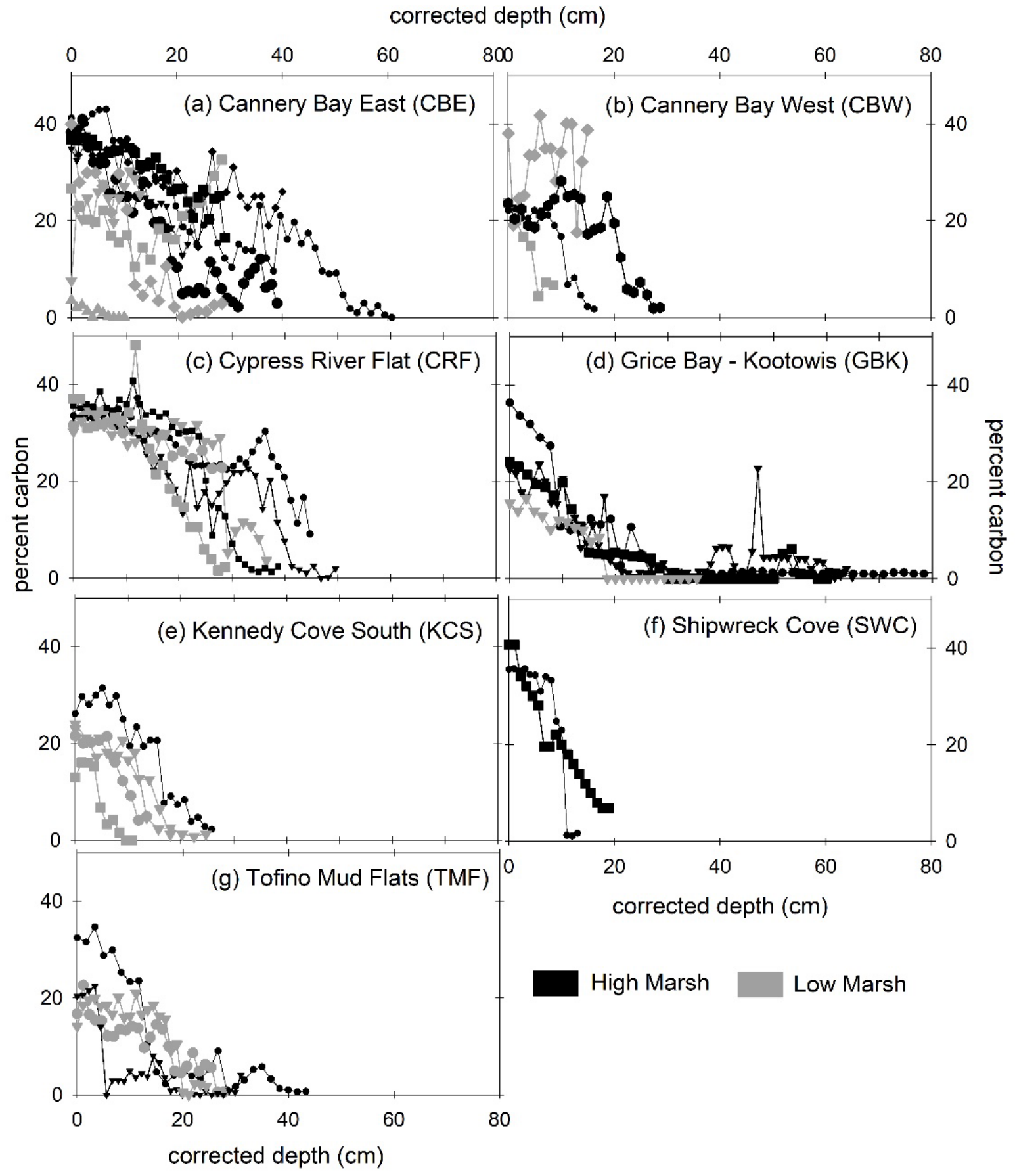


https://doi.org/10.5194/bg-2021-157

Preprint. Discussion started: 8 July 2021

(c) Author(s) 2021. CC BY 4.0 License.

Figure 2. Percent Carbon (vertical axis) versus depth (horizontal axis) for high marsh (black) and low marsh (grey) cores at all sites. Marsh name abbreviations are defined in Fig. 1. Depths have been corrected for core compaction.
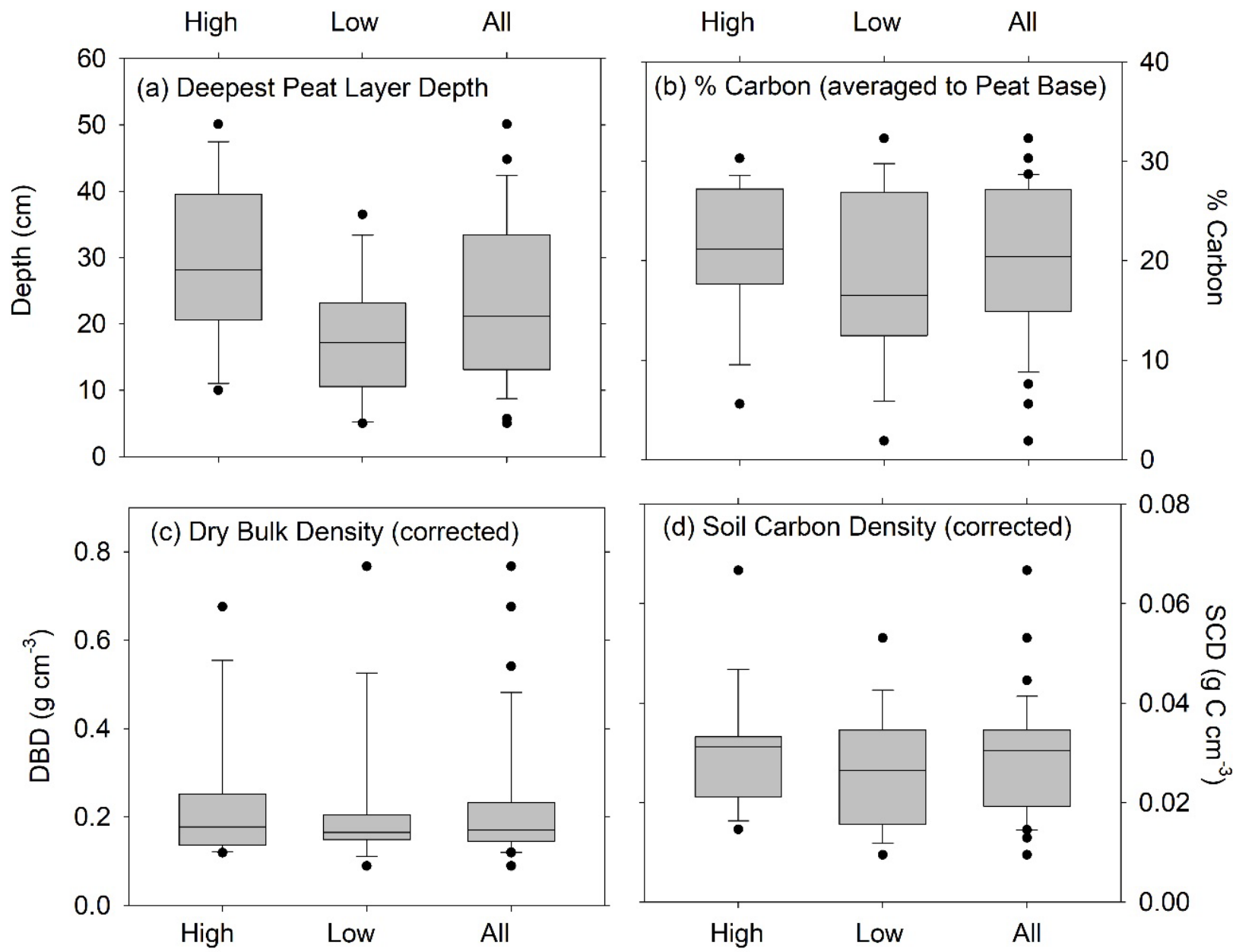

Figure 3. Distributions of (a) deepest depth of peat overlying sand, gravel, or clay (cm), (b) average percent carbon, (c) average dry bulk density (corrected for compaction), and (d) average soil carbon density (corrected for compaction). (b), (c), and (d) are estimated to the deepest peat depth for cores in the high marsh zones, low marsh zones, and all cores combined. Horizontal bar is the median; ends of the boxes represent the upper and lower quartiles; whiskers indicate minimum and maximum values while dots indicate outliers. Differences between depths of deepest peat layer for high and low marshes are statistically significant $(t=$ 2.86, $\mathrm{p}$-value $=\mathbf{0 . 0 0 8 6})$. Unpaired t-tests show that the high and low marsh values are not statistically different for $\% \mathrm{C}(\mathrm{t}=1.03$, $\mathrm{p}$ value $=0.31), \operatorname{DBD}(\mathrm{t}=0.25, \mathrm{p}$-value $=0.80)$, and $\operatorname{SCD}(\mathrm{t}=0.91, \mathrm{p}$-value $=0.37)$.

\subsection{Carbon Stocks and Total Carbon Storage}

265 The seven marshes ranged in size from 0.5 to 27 ha, with a total area of 47 ha (Table 1). The high marsh comprised $19-63 \%$ of each individual marsh area and $58 \%$ of the area of all seven marshes combined (Table 1). 
https://doi.org/10.5194/bg-2021-157

Preprint. Discussion started: 8 July 2021

(c) Author(s) 2021. CC BY 4.0 License.

The average $\mathrm{C}$ stock to the base peat layer for all cores was $67 \pm 9 \mathrm{Mg} \mathrm{C}^{-1}$ (mean $\pm \mathrm{SE}$ ). The base of peat $\mathrm{C}$ stock estimates for the high marshes $\left(80 \pm 14 \mathrm{Mg} \mathrm{C}\right.$ ha $\left.^{-1}\right)$ were 1.5 -fold higher than those found in low marsh cores $(52 \pm 8 \mathrm{Mg} \mathrm{C}$ ha $^{-1}$, unpaired t test, $\mathrm{p}<0.05$ ) (Fig. 4 and 5, Table 1).

Similar results were obtained when $\mathrm{C}$ stocks were calculated only for the upper $20 \mathrm{~cm}$ (Fig. 4, Table 1). The average 20-cm $\mathrm{C}$ stock was $54 \pm 5 \mathrm{Mg} \mathrm{C}^{-1}$. High marshes averaged $64 \pm 6 \mathrm{Mg} \mathrm{C}^{-1}$, which was statistically higher than the low marsh average of $43 \pm 7 \mathrm{Mg} \mathrm{Cha}^{-1}(\mathrm{p}<0.05)$. An average of $81 \%$ of the total $\mathrm{C}$ stocks in a core accumulates in the top $20 \mathrm{~cm}$ of soil.

Summing $\mathrm{C}$ stocks to the 30 -year horizon of the eight dated cores results in an average of $56 \pm 14 \mathrm{Mg} \mathrm{C}^{-1}$ (Table 1; Fig.

4). Using the 30-year horizon accentuates the statistically significant difference in $C$ stocks accumulating in the high vs low marsh zones $(\mathrm{p}<0.05)$, with high marsh $\mathrm{C}$ stocks $\left(87 \pm 16 \mathrm{Mg} \mathrm{C}^{-1}\right)$ up to $\sim 4$ times higher than those found in low marshes $\left(24 \pm 2 \mathrm{Mg} \mathrm{C}^{-1}\right)$.

When combined with our estimates of marsh area, we calculate that the total C storage of these seven marshes was $4189 \pm$ $303 \mathrm{Mg} \mathrm{C}, 69 \%$ of which was stored in the high marsh (Table 2; Fig. 5c). For only the top $20 \mathrm{~cm}$, this total is $2764 \pm 149$

$280 \mathrm{Mg} \mathrm{C}, 63 \%$ of which accumulated in the high marsh zones. Finally, over the last 30 years, $2852 \pm 438 \mathrm{Mg} \mathrm{C}$ have accumulated in these marshes, $84 \%$ of which accumulated in the high marsh zones (Table 1).

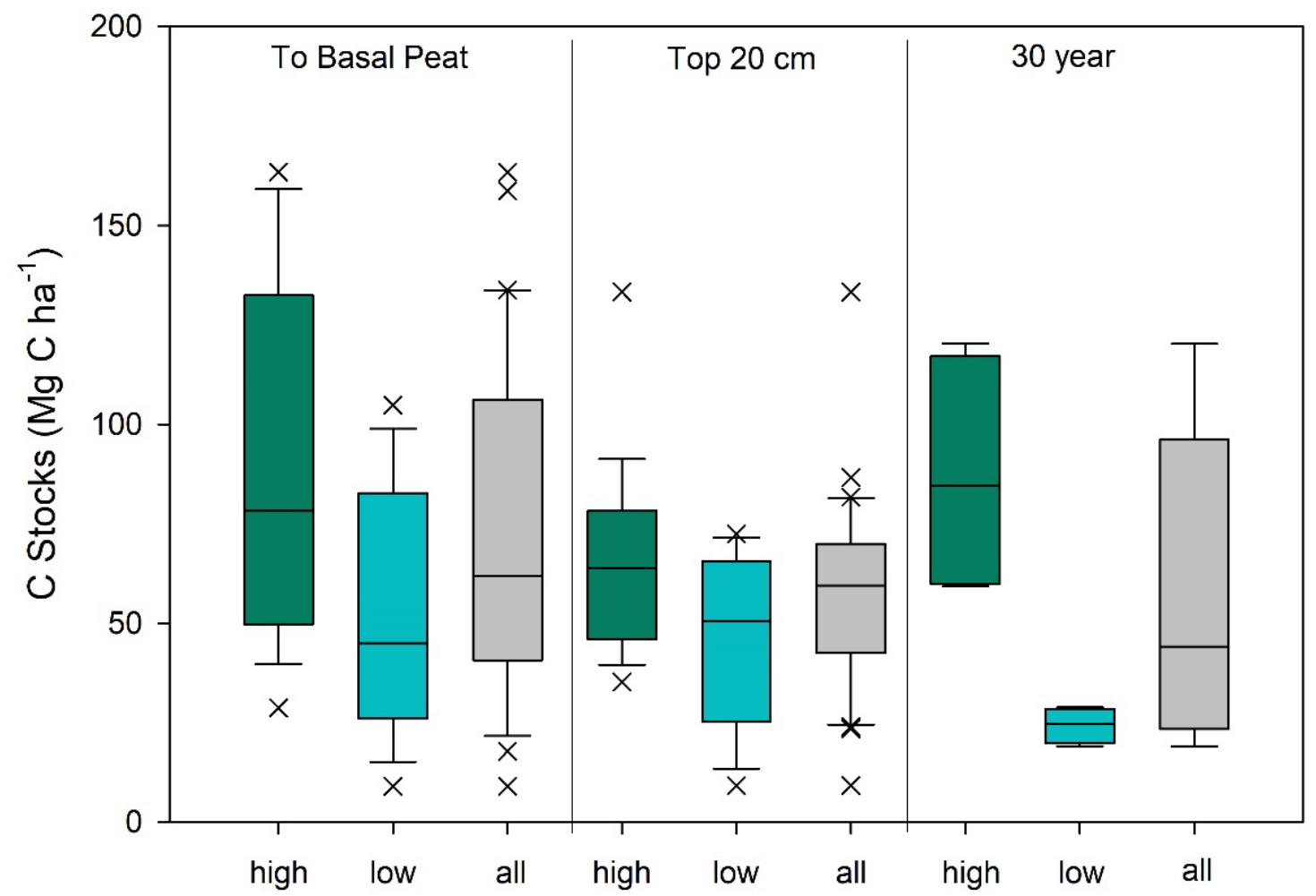

Figure 4. Carbon stock estimates for Clayoquot Sound for the high marsh zone (green), low marsh zone (blue), and combined (grey) for all cores. Estimates are made to the base of peat layer, for the surface $20 \mathrm{~cm}$, and for the most recent $30 \mathrm{years}$ of 
https://doi.org/10.5194/bg-2021-157

Preprint. Discussion started: 8 July 2021

(c) Author(s) 2021. CC BY 4.0 License.

\section{(c) (i)}

accretion. Note that 30-yr values are based on 4 cores each for high and low marshes (see Methods). Unpaired t-tests show statistically significant differences between the high and low marsh $\mathrm{C}$ stocks calculated to the base of peat depth $(\mathrm{t}=2.91$, $\mathrm{p}$-value $=0.0065), 20-\mathrm{cm} C$ stocks $(t=2.20$, $p$-value $=0.036)$ and 30-year $C$ stocks $(t=3.95$, $p$-value $=0.0074)$.

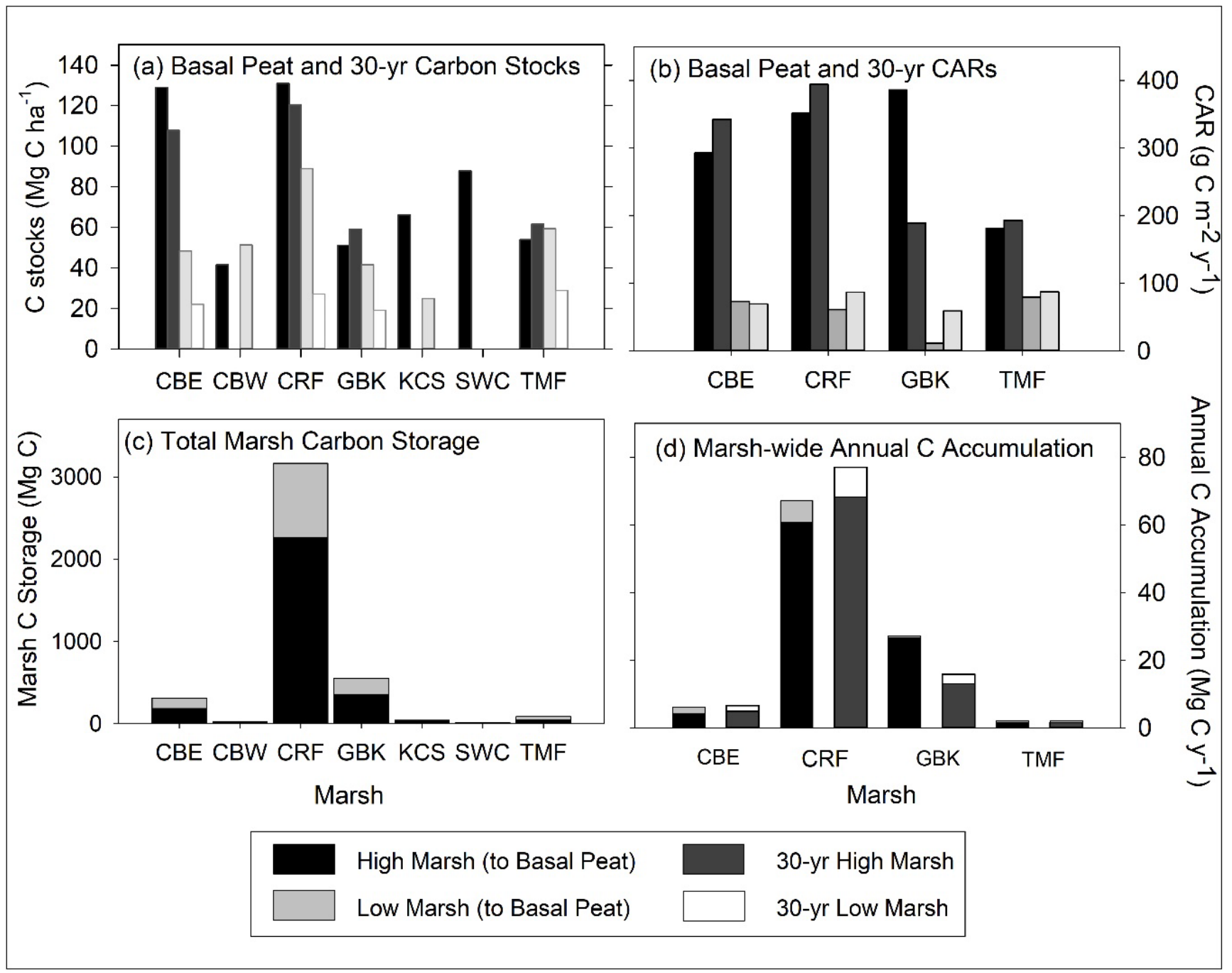

Figure 5. (a) High and low marsh carbon stocks $\left(\mathrm{Mg} \mathrm{C} \mathrm{ha}^{-1}\right)$ measured to the base of peat layer and for the last 30 years; (b) High and low marsh carbon accumulation rates (CARs, $\mathrm{g} \mathrm{C} \mathrm{m}^{-2} \mathrm{y}^{-1}$ ) measured to the base of peat layer and for the last 30 years; (c) total marsh carbon (Mg C) estimate to the base of peat layer for high and low marsh zones of each marsh, and (d) marsh wide annual $\mathrm{C}$ accumulation (Mg C y-1) estimated to the base of peat layer and for the last 30 years. Paired differences between high and low marsh CARs are statistically significant for CARs calculated to the base of peat layer $(t=4.283$, $p$-value $=0.0234)$ and for 30 -yr CARs (t=4.043, p-value = 0.0272). (Statistical comparisons of C stocks are in Fig. 4). 
https://doi.org/10.5194/bg-2021-157

Preprint. Discussion started: 8 July 2021

(c) Author(s) 2021. CC BY 4.0 License.

Table 1. Carbon Stocks

\begin{tabular}{|c|c|c|c|c|c|c|}
\hline \multirow{2}{*}{ Site } & \multirow{2}{*}{$\begin{array}{l}\text { Marsh } \\
\text { Area (ha) }\end{array}$} & \multicolumn{3}{|c|}{ Carbon Stock $\left(\mathrm{Mg} \mathrm{C} \mathrm{ha}^{-1}\right)$, Ave $\pm \mathrm{SE}$} & \multicolumn{2}{|c|}{ Total Carbon (Mg C), Ave \pm SE } \\
\hline & & To Peat Base & Top $20 \mathrm{~cm}$ & $30-\mathbf{y r}$ & To Peat Base & Top $20 \mathrm{~cm}$ \\
\hline \multicolumn{7}{|c|}{ High Marsh } \\
\hline $\mathrm{CBE}$ & 1.42 & $129 \pm 11$ & $74 \pm 4$ & 108 & $183 \pm 16$ & $106 \pm 6$ \\
\hline CBW & 0.27 & $41 \pm 13$ & $47 \pm 0.4$ & & $11 \pm 3$ & $13 \pm 0.1$ \\
\hline CRF & 17.31 & $131 \pm 16$ & $70 \pm 7$ & 120 & $2266 \pm 283$ & $1214 \pm 121$ \\
\hline GBK & 6.9 & $51 \pm 6$ & $47 \pm 9$ & 59 & $353 \pm 41$ & $322 \pm 63$ \\
\hline KCS & 0.47 & 66 & 66 & & 31 & 31 \\
\hline SWC & 0.2 & $88 \pm 46$ & $89 \pm 45$ & & $18 \pm 9$ & $18 \pm 9$ \\
\hline TMF & 0.82 & $54 \pm 9$ & $52 \pm 9$ & 61.5 & $44 \pm 7$ & $42.5 \pm 7.5$ \\
\hline Ave \pm SE & --- & $80 \pm 14$ & $64 \pm 6$ & $87 \pm 16$ & --- & --- \\
\hline $\operatorname{Sum} \pm \varepsilon$ & 27.4 & --- & --- & --- & $2906 \pm 287$ & $1746 \pm 137$ \\
\hline \multicolumn{7}{|c|}{ Low Marsh } \\
\hline CBE & 2.57 & $46 \pm 16$ & $38 \pm 16$ & 22 & $118 \pm 41$ & $99 \pm 40$ \\
\hline CBW & 0.23 & $51 \pm 34$ & 23 & & $12 \pm 8$ & 5 \\
\hline $\mathrm{CRF}$ & 10.11 & $89 \pm 8$ & $66 \pm 4$ & 27 & $899 \pm 85$ & $663 \pm 43$ \\
\hline GBK & 4.79 & 42 & 42 & 19 & 199 & 199 \\
\hline $\mathrm{KCS}$ & 0.32 & $25 \pm 2$ & $24 \pm 4$ & & $8 \pm 0.8$ & $7.5 \pm 1$ \\
\hline SWC & 0.83 & --- & --- & & --- & --- \\
\hline TMF & 0.69 & $59 \pm 6$ & $63 \pm 6$ & 29 & $41 \pm 4$ & $44 \pm 4$ \\
\hline Ave \pm SE & --- & $52 \pm 8$ & $43 \pm 7$ & $24 \pm 2$ & --- & --- \\
\hline $\operatorname{Sum} \pm \varepsilon$ & 19.5 & --- & --- & & $1283 \pm 97$ & $1018 \pm 59$ \\
\hline \multicolumn{7}{|c|}{ Total Marsh } \\
\hline Ave \pm SE & --- & $67 \pm 9$ & $54 \pm 5$ & $56 \pm 14$ & --- & --- \\
\hline $\operatorname{Sum} \pm \varepsilon$ & 46.9 & --- & --- & & $4189 \pm 303$ & $2764 \pm 149$ \\
\hline
\end{tabular}

Base of peat $\mathrm{C}$ stock was estimated by summing the mass of carbon from each 1-cm sample interval to the base of each core. Base of peat $\mathrm{C}$ stock values are averages of multiple cores, except where only one core was collected (e.g., high marsh KCS and low marsh GBK). The 30-yr high and low marsh average $\mathrm{C}$ stocks are based only on CBE, CRF, GBK, and TMF. 30-y marsh carbon (Mg C) is estimated by multiplying high marsh areas by average high marsh 30-yr C stocks (2384 $\pm 438 \mathrm{Mg} \mathrm{C})$, low marsh area by average low marsh 30 -yr C stock (468 $\pm 19 \mathrm{Mg} \mathrm{C})$, which is summed to get a total of $2852 \pm 438 \mathrm{Mg} \mathrm{C})$.

\subsection{Age-depth relationships and mass accumulation rates over time}

305 Activities of ${ }^{210} \mathrm{~Pb}$ ranged from 2 to $372 \mathrm{~Bq} \mathrm{~kg}^{-1}$, with maximum activities found at the surface. Activities of ${ }^{226} \mathrm{Ra}$ ranged from 1.6-4.3 $\mathrm{Bq} \mathrm{kg}-1$ and were subtracted from the ${ }^{210} \mathrm{~Pb}_{\text {total }}$ to obtain the excess ${ }^{210} \mathrm{~Pb}\left({ }^{210} \mathrm{~Pb}_{\mathrm{xs}}\right)$. For most of the cores, the ${ }^{210} \mathrm{~Pb}_{\text {sup }}$ level was not reached. Only GBK 1-4 and TMF $1-2$ showed a complete ${ }^{210} \mathrm{~Pb}_{\mathrm{xs}}$ profile. 
https://doi.org/10.5194/bg-2021-157

Preprint. Discussion started: 8 July 2021

(c) Author(s) 2021. CC BY 4.0 License.

(c) (i)

Discussions

Activities of ${ }^{210} \mathrm{~Pb}_{\mathrm{xs}}$ showed an almost monotonic decline with depth, suggesting that processes such as bioturbation, mixing, or disconformities have not disturbed the records, and the logarithmic ${ }^{210} \mathrm{~Pb}_{\mathrm{xs}}$ profile plotted against the cumulative mass resulted in a linear profile (Fig. 6).

\subsection{Mass Accumulation Rates and Carbon Accumulation Rates}

The "basal age", defined as the age at the base of the deepest peat layer, ranged from 13 to 140 years (Table 2). At all sites, the basal ages are consistently older in low marsh cores (106 $\pm 17 \mathrm{yrs)}$ when compared to high marsh cores (33 \pm 9 yrs). As a result, the MARs were an order of magnitude higher in high marsh zones compared to low ones, with average 315 MAR of $3978 \pm 1231$ and $399 \pm 67 \mathrm{~g} \mathrm{~m}^{-2} \mathrm{yr}^{-1}$ in the low marsh sediment, respectively, averaging $2188 \pm 885 \mathrm{~g} \mathrm{~m}^{-2} \mathrm{yr}^{-1}$ (range 262-6977 $\mathrm{g} \mathrm{m}^{-2} \mathrm{yr}^{-1}$ ) for the whole marsh (Table 2).

The average base of peat CAR for the dated cores was $184 \pm 50 \mathrm{~g} \mathrm{C} \mathrm{m}^{-2} \mathrm{yr}^{-1}$ (range 47 to $386 \mathrm{~g} \mathrm{C} \mathrm{m}^{-2} \mathrm{yr}^{-1}$, Table 2). Similar value was obtained by using the 30-year average CARs, with an average of $178 \pm 46 \mathrm{~g} \mathrm{C} \mathrm{m}^{-2} \mathrm{yr}^{-1}$ (range 59 to $394 \mathrm{~g} \mathrm{C} \mathrm{m}^{-2} \mathrm{yr}^{-}$ ${ }^{1}$ ) (Table 2; Fig. 5b). In the base of peat estimates, CARs in the four high marsh cores (average $303 \pm 45 \mathrm{~g} \mathrm{C} \mathrm{m}^{-2} \mathrm{yr}^{-1}$ ) were 320 significantly higher than the low marsh core average $\left(63 \pm 7 \mathrm{~g} \mathrm{C} \mathrm{m}^{-2} \mathrm{yr}^{-1} ; \mathrm{p}<0.05\right)$. This difference was also apparent when comparing the 30-year average CARs $\left(280 \pm 52 \mathrm{~g} \mathrm{C} \mathrm{m}^{-2} \mathrm{yr}^{-1}\right.$ and $76 \pm 7 \mathrm{~g} \mathrm{C} \mathrm{m}^{-2} \mathrm{yr}^{-1}$ for high and low marsh, respectively, $\mathrm{p}<$ $0.05)$.

When we use the high and low marsh areas with the average of the CARs calculated to the base of the peat in each core, we find that the high marsh accumulates $83 \pm 12 \mathrm{Mg} \mathrm{C} \mathrm{yr}^{-1}$, and the low marsh accumulates $13 \pm 1.4 \mathrm{Mg} \mathrm{C} \mathrm{yr}^{-1}$ (Fig. 5c, Table

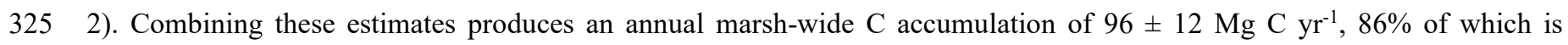
accumulating annually in the high marsh zones. Similar results are obtained when using the 30-yrs CARs, with high marshes accumulating $85 \%$ of marsh-wide annual $\mathrm{C}$ accumulation ( $\left.77 \pm 14 \mathrm{Mg} \mathrm{C} \mathrm{yr}^{-1}\right)$ (Table 2). 
https://doi.org/10.5194/bg-2021-157

Preprint. Discussion started: 8 July 2021

(C) Author(s) 2021. CC BY 4.0 License.

Table 2. Core and Marsh Wide Carbon Accumulation Rates

\begin{tabular}{|c|c|c|c|c|c|c|c|c|}
\hline \multirow{2}{*}{ Site } & \multirow{2}{*}{$\begin{array}{l}\text { Area } \\
\text { (ha) }\end{array}$} & \multicolumn{2}{|c|}{$\begin{array}{c}\text { Carbon } \\
\text { Accumulation Rate } \\
\left(\mathrm{CAR}, \mathrm{g} \mathrm{C} \mathrm{m}^{-2} \mathbf{y}^{-1}\right)\end{array}$} & \multicolumn{2}{|c|}{$\begin{array}{c}\text { Marsh wide Carbon } \\
\text { Accumulation } \\
\left(\mathrm{Mg} \mathrm{C}^{-1}\right), \text { Ave } \pm \mathrm{SE}\end{array}$} & \multicolumn{3}{|c|}{ Sedimentation Characteristics, Ave $\pm \mathrm{SE}^{\mathrm{c}}$} \\
\hline & & $30-y r$ & $\begin{array}{l}\text { Peat } \\
\text { Base }\end{array}$ & $30-y r$ & Peat Base & $\begin{array}{l}\text { (years } \\
\text { before } \\
2016)^{d}\end{array}$ & $\begin{array}{l}\text { LSR } \\
\left(\mathrm{cm} \mathrm{yr}^{-1}\right)\end{array}$ & $\begin{array}{l}\text { MAR } \\
\left(\mathrm{g} \mathrm{cm-}^{2} \mathrm{yr}^{-1}\right)\end{array}$ \\
\hline \multicolumn{9}{|c|}{ High Marsh } \\
\hline CBE 1-1 & 1.42 & $342 \pm 25$ & $293 \pm 21$ & $4.9 \pm 0.4$ & $4.2 \pm 0.3$ & $54.1 \pm 3.9$ & $0.97 \pm 0.56$ & $0.156 \pm 0.011$ \\
\hline CRF 2-1 & 17.31 & $394 \pm 41$ & $352 \pm 37$ & $68.2 \pm 7.1$ & $60.9 \pm 6.4$ & $26.7 \pm 2.8$ & $1.08 \pm 0.55$ & $0.242 \pm 0.025$ \\
\hline GBK 1-2 & 6.9 & $189 \pm 9$ & $386 \pm 18$ & $13.0 \pm 0.6$ & $26.6 \pm 1.2$ & $13.3 \pm 0.6$ & $1.80 \pm 1.40$ & $0.697 \pm 0.033$ \\
\hline TMF 2-1 & 0.82 & $193 \pm 8$ & $182 \pm 8$ & $1.6 \pm 0.1$ & $1.5 \pm 0.1$ & $38.5 \pm 1.7$ & $1.00 \pm 0.80$ & $0.496 \pm 0.022$ \\
\hline $\operatorname{Ave} \pm \mathbf{S E}$ & $27.4^{\mathrm{a}}$ & $\begin{array}{l}279.5 \pm \\
52\end{array}$ & $303 \pm 45$ & $76.6 \pm 14.3$ & $83 \pm 12$ & $33.2 \pm 8.7$ & $1.21 \pm 0.20$ & $0.40 \pm 0.12$ \\
\hline \multicolumn{9}{|c|}{ Low Marsh } \\
\hline CBE $1-5$ & 2.57 & $69 \pm 21$ & $65 \pm 20$ & $1.8 \pm 0.5$ & $1.9 \pm 0.6$ & $131.4 \pm 39.4$ & $0.175 \pm 0.060$ & $0.0346 \pm 0.0104$ \\
\hline CRF 3-2 & 10.11 & $87 \pm 20$ & $62 \pm 14$ & $8.8 \pm 2.0$ & $6.3 \pm 1.4$ & $139.5 \pm 32.5$ & $0.167 \pm 0.075$ & $0.0262 \pm 0.0061$ \\
\hline GBK 1-4 & 4.79 & $59 \pm 12$ & $47 \pm 10$ & $2.8 \pm 0.6$ & $2.3 \pm 0.5$ & $87.8 \pm 18.5$ & $0.133 \pm 0.19$ & $0.0408 \pm 0.086$ \\
\hline TMF 1-2 & 0.69 & $88 \pm 10$ & $80 \pm 9$ & $0.6 \pm 0.1$ & $0.6 \pm 0.1$ & $66.7 \pm 7.6$ & $0.36 \pm 0.27$ & $0.0579 \pm 0.0066$ \\
\hline Ave \pm SE & $19.5^{\mathrm{a}}$ & $76 \pm 8.2$ & $63.5 \pm 7$ & $14.8 \pm 1.4$ & $13 \pm 1.4$ & $106.3 \pm 17.4$ & $0.21 \pm 0.051$ & $0.040 \pm 0.0067$ \\
\hline \multicolumn{9}{|c|}{ Total Marsh } \\
\hline Ave \pm SE & $46.9^{\mathrm{a}}$ & $178 \pm 46$ & $184 \pm 50$ & $83 \pm 21^{e}$ & $86 \pm 23^{\mathrm{e}}$ & $69.7 \pm 16.5$ & $0.711 \pm 0.212$ & $0.219 \pm 0.089$ \\
\hline
\end{tabular}

330 a Marsh areas represent the sums for the high, low, and total marsh.

${ }^{b}$ Marsh-wide Carbon Accumulation rates are estimated as the average (high, low, total) CAR multiplied by the marsh area (first column) for all seven marshes.

${ }^{\mathrm{c}}$ Associated DBDs, \%C, and SCD values are in Table A1.

${ }^{\mathrm{d} B a s a l}$ Age reflects age determined in deepest sediment layer containing peat overlying sand, clay, or gravel.

335 'The total marsh-wide carbon accumulation values stated here are based on using the average total marsh CAR multiplied by the total marsh area. The values stated in the text are slightly higher because they are based on adding the low marsh and high marsh annual carbon accumulation values together. 
https://doi.org/10.5194/bg-2021-157

Preprint. Discussion started: 8 July 2021

(c) Author(s) 2021. CC BY 4.0 License.

(c) (i)
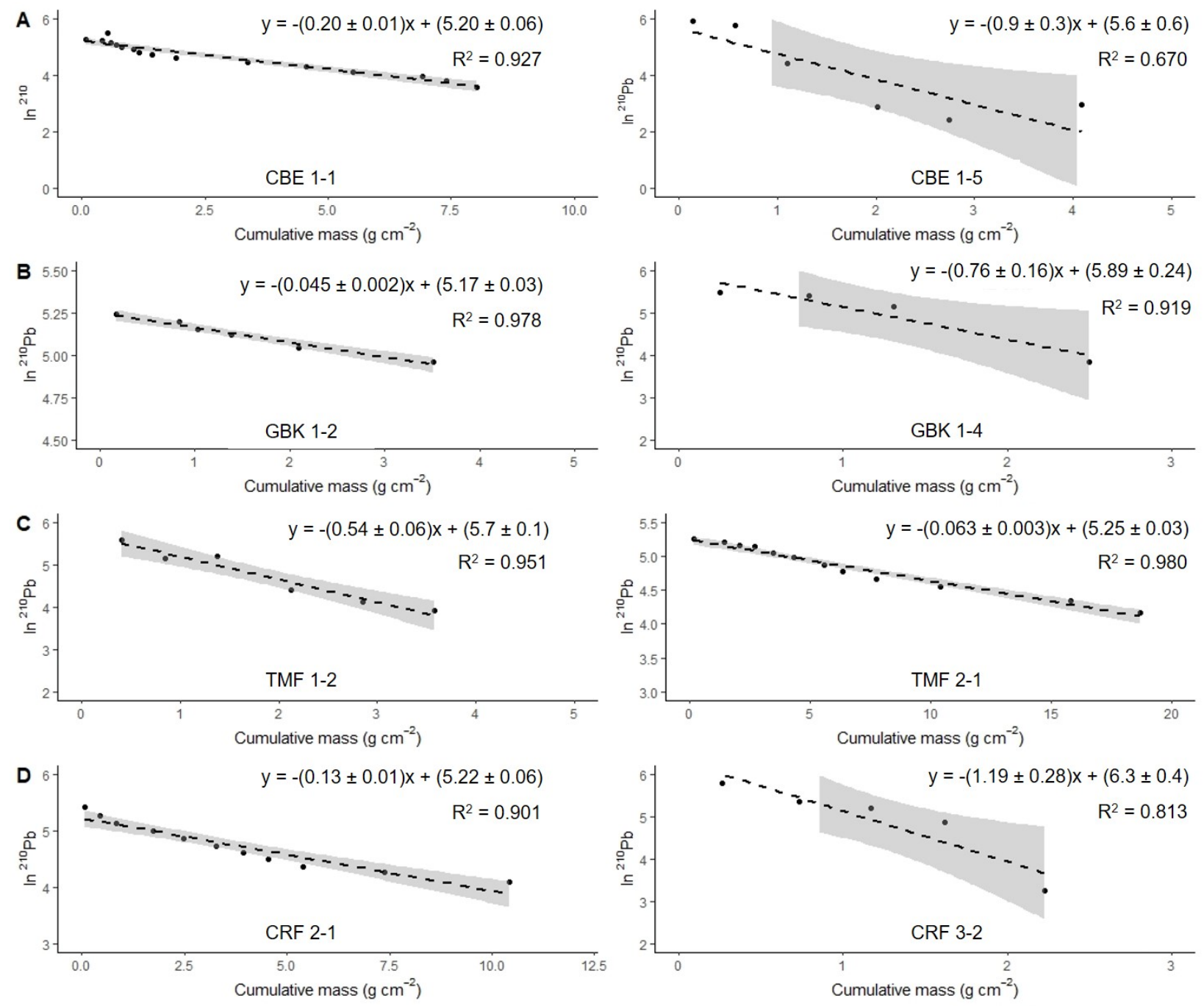

Figure 6. Natural $\log$ of Excess ${ }^{210} \mathrm{~Pb}$ activity versus cumulative mass from the surface. The equation in each graph shows the results from the regression analyses used for the calculation of the mean accumulation rate $\left(\mathrm{g} \mathrm{cm}^{-2} \mathrm{y}^{-1}\right) \mathrm{using}$ the $\mathrm{CF}$ : $\mathrm{CS}$ model. Grey shaded area represents $95 \%$ confidence intervals.

\section{Discussion}

\subsection{Carbon Stocks}

We calculate that the total C storage from salt marshes in Clayoquot Sound is $4189 \pm 303 \mathrm{Mg} \mathrm{C}$, with only $31 \%$ accumulated in the low marsh (see Sect. 3.2). Similar, small contributions from the low marsh zone have been found in other estuarine systems (Connor et al. 2001; Adams et al. 2012). In nearby Boundary Bay, BC, Gailis et al. (2021) also found that the low marsh contributed a disproportionately small fraction (15\%) to the total marsh-wide $\mathrm{C}$ stocks relative to their area. As with Boundary Bay, we found that the small low marsh contribution was driven in part by the smaller proportion of low marsh 
https://doi.org/10.5194/bg-2021-157

Preprint. Discussion started: 8 July 2021

(c) Author(s) 2021. CC BY 4.0 License.

area (42\% of total) in Clayoquot Sound. Gailis et al. (2021) also attributed lower C stocks in low marsh sediments to vegetation type and associated rooting depths (which are shallower in low marsh Salicornia spp). Similar differences in vegetation are observed in the Clayoquot Sound marshes. Furthermore, when normalized to a constant depth horizon (20 $\mathrm{cm}$ ), the C stocks in Clayoquot Sound low marsh zones are 28\% lower than those in the high marsh zones (Fig. 4). However, the main drivers of the smaller $\mathrm{C}$ stocks are significantly shallower depths of the base of the peat layer in low marsh relative to the high marsh cores in Clayoquot Sound (Fig. 3a). High marsh peat layers are on average $71 \%$ thicker than those found in the low marsh zones, suggesting that low marsh sediments are simply too shallow to accumulate as much $\mathrm{C}$ as the high marsh zones.

The $\mathrm{C}$ stocks in Clayoquot Sound marshes are less than one-third of the globally averaged estimate of $250 \mathrm{Mg} \mathrm{C}^{-1}$ for salt marsh C stocks (Chmura et al. 2003; Pendleton et al. 2012). This is true whether we consider the base of peat, 20-cm, or 30yr estimates (Table 1). The $\mathrm{C}$ stocks in these seven Clayoquot Sound marshes are consistent with regional values found in Boundary Bay, $\mathrm{BC}\left(83 \pm 30\right.$ and $39 \pm 24 \mathrm{Mg} \mathrm{C}$ ha $^{-1}$ for high and low marsh, respectively, Gailis et al. 2021), in Stillaguamish, Washington (60 $\pm 4 \mathrm{Mg} \mathrm{C}^{-1}$; Poppe and Rybczyk, 2019), and Snohomish estuary, Washington (72 $\mathrm{Mg} \mathrm{C}^{-1}$ and $54 \mathrm{Mg} \mathrm{C}$ $\mathrm{ha}^{-1}$ for the top $30 \mathrm{~cm}$ of two marshes, Crooks et al., 2014). However, these C stocks are an order of magnitude lower than estimates of total soil $\mathrm{C}$ mass in high and low marshes along the Pacific coast of the USA (543 \pm 47 and $411 \pm 70 \mathrm{Mg} \mathrm{C} \mathrm{ha}^{-1}$, respectively (Kauffman et al. 2020)).

The lower overall $\mathrm{C}$ stocks in these Pacific marshes may in part be attributable to a lower overall $\mathrm{C}$ content: the average soil $\mathrm{C}$ density of the seven Clayoquot Sound marshes is $0.027 \pm 0.002 \mathrm{~g} \mathrm{C} \mathrm{cm}^{-3}$, which is lower than regional estimates for the Oregon Coast $\left(0.034 \pm 0.011 \mathrm{~g} \mathrm{C} \mathrm{cm}^{-3}\right.$; Peck et al. 2020) and the global mean of $0.039 \pm 0.003 \mathrm{~g} \mathrm{C} \mathrm{cm}^{-3}$ (Chmura et al.

370 2003). However, low overall $\mathrm{C}$ content is not likely to be the main cause of the lower $\mathrm{C}$ stocks overall because these SCDs are comparable to the means for the US $\left(0.028 \pm 0.013 \mathrm{~g} \mathrm{C} \mathrm{cm}^{-3}\right.$; Holmquist et al. 2018) and Pacific Northwest marshes $\left(0.023 \pm 0.002 \mathrm{~g} \mathrm{C} \mathrm{cm}^{-3}\right)$ in which $\mathrm{C}$ stocks are an order of magnitude higher than Clayoquot Sound (Kauffman et al. 2020).

A more likely cause is simply the shallow thickness of the Clayoquot Sound marshes, with the depth to the base of the deepest peat layer averaging $23 \pm 2 \mathrm{~cm}$ (17 cm for low marsh and 29 for high marsh). Similarly shallow depths of refusal

375 (penetrating into sand or clay layers) have been found in seagrass beds of Clayoquot Sound (Postlethwaite et al. 2018) as well as in Boundary Bay marsh (Gailis et al., 2021). In contrast, a sampling of seagrass and salt marsh systems along the US Pacific Coasts suggest that these ecosystems have substantially thicker soil $\mathrm{C}$ depths, with $>85 \%$ having mean soil profile depths greater than $2 \mathrm{~m}$ (Kauffman et al. 2020). Because data represented in many syntheses come from regions with marshes that have depths of one meter or greater (e.g. Macreadie et al. 2017), extrapolating the results to the total marsh area

380 likely overestimates total $\mathrm{C}$ storage. Thus, we recommend that ongoing work to assess blue $\mathrm{C}$ contents globally begin to consider shallower depth horizons and/or age horizons as a means for creating a global comparison. 
https://doi.org/10.5194/bg-2021-157

Preprint. Discussion started: 8 July 2021

(c) Author(s) 2021. CC BY 4.0 License.

\subsection{Carbon Accumulation Rates, Comparisons of Marsh Zones and Pacific Coast Marshes}

While marsh C stocks in Clayoquot Sound are substantially lower than the global and Pacific coast averages, the average CARs are actually higher than those found in other parts of the Pacific Coast, especially when we separate measurements by marsh zone (Fig. 7). When all ${ }^{210} \mathrm{~Pb}$-dated sites are combined, we obtain an average CAR for the NE Pacific region of $112 \pm$ $12 \mathrm{~g} \mathrm{C} \mathrm{m}^{-2} \mathrm{yr}^{-1}$ (mean $\pm \mathrm{SE}, \mathrm{n}=18$ ). While this value is comparable to the global average CAR of $91 \pm 2.3$ (IPCC (2013)), both are substantially lower than the regionally averaged CAR of $184 \pm 50 \mathrm{~g} \mathrm{C} \mathrm{m}^{-2} \mathrm{yr}^{-1}$ for Clayoquot Sound (Fig. 7c). When we consider only high marsh cores, the average CAR for Clayoquot Sound further increases to $303 \pm 45 \mathrm{~g} \mathrm{C} \mathrm{m}^{-2} \mathrm{yr}^{-1}$, substantially larger than the NE Pacific high-marsh average of $145 \pm 26 \mathrm{~g} \mathrm{C} \mathrm{m}^{-2} \mathrm{yr}^{-1}$ (Fig. 7a). In fact, the NE Pacific high marsh average is driven substantially by the inclusion of Clayoquot Sound marshes and drops to $96 \pm 12 \mathrm{~g} \mathrm{C} \mathrm{m}^{-2} \mathrm{yr}^{-1} \mathrm{when}$ Clayoquot Sound marshes are excluded. This comparison suggests that while the overall $\mathrm{C}$ storage in Clayoquot Sound marshes is low, the current rates of accumulation are much higher than the regional average, particularly in the high marsh zones. Thus, assuming these rates of $\mathrm{C}$ accumulation continue, high marsh zones of Clayoquot Sound have the potential to play a more important role as $\mathrm{C}$ sinks in the future.

395 We note, however, that our new average estimate for NE Pacific CARs of $112 \pm 12 \mathrm{~g} \mathrm{C} \mathrm{m}^{-2} \mathrm{yr}^{-1}$ is substantially lower than estimates compiled by Ouyang and Lee (2014), whether considering the global average (245 $\left.\mathrm{g} \mathrm{C} \mathrm{m}^{-2} \mathrm{yr}^{-1}\right)$, the NE Pacific average ( $167 \mathrm{~g} \mathrm{C} \mathrm{m}^{-2} \mathrm{yr}^{-1}, \mathrm{n}=6$ ), the NW Atlantic region $\left(172 \mathrm{~g} \mathrm{C} \mathrm{m}^{-2} \mathrm{yr}^{-1} ; \mathrm{n}=64 ; 35.0-47.4{ }^{\circ} \mathrm{N}\right)$, or the subset of cores from Atlantic Canada $\left(188 \mathrm{~g} \mathrm{C} \mathrm{m}^{-2} \mathrm{yr}^{-1} ; \mathrm{n}=40 ; 43.6-47.4^{\circ} \mathrm{N}\right)$. For the NE Pacific region, this compilation predominantly included sites where ${ }^{137} \mathrm{Cs}$-dating was used to estimate CARs (Ouyang and Lee, 2014). The remaining NE Pacific CAR studies ( $\mathrm{n}=2$ ) used marker horizon methods, which, when included, increase the average CAR to $174 \pm 128 \mathrm{~g} \mathrm{C} \mathrm{m}-2 \mathrm{yr}-1$. Marker horizon and $137 \mathrm{Cs}$ dating methods are shown to produce CARs higher than those calculated from ${ }^{210} \mathrm{~Pb}$ (Chmura et al. 2003; Callaway et al. 2012). This is due to gradual decomposition in the sediment column, averaging CAR over a shorter time period, and to a shallower depth, oversampling high $\mathrm{C}$ soils vis-à-vis lower $\mathrm{C}$ soils at depth. As most of the CAR data points in the NW Atlantic region in Ouyang and Lee's 2014 summary were also calculated using ${ }^{137} \mathrm{Cs}$ dating or marker horizon methods ( $n=62$ ), these also represent roughly equivalent values to Clayoquot Sound if the observed bias is considered.

Differences between Clayoquot Sound and regionally averaged CARs are not apparent for low marsh zone, for which the Clayoquot Sound average of $63 \pm 7 \mathrm{~g} \mathrm{C} \mathrm{m}^{-2} \mathrm{yr}^{-1}$ is statistically similar to the regional estimate of $74 \pm 6 \mathrm{~g} \mathrm{C} \mathrm{m}^{-2} \mathrm{yr}^{-1}$ (Fig. 7b). Within the context of Clayoquot Sound, the low marsh zone exhibits substantially lower $\mathrm{C}$ stocks and accumulation rates than the high marsh zones. Basal ages (age of the deepest peat layer overlying sand) are substantially older in low marsh sediments when compared to the high marsh, resulting in significantly lower sedimentation rates and CARs.

Our observation of significantly lower CARs in the low marsh compared to the high marsh could result from several factors. As mentioned previously, the vegetation in the low marsh zone is dominated by Salicornia spp, whose lower productivity and shallow root systems could be producing and trapping less C (Kelleway et al. 2017; Gailis et al. 2021). A second, potential contributor to slow accumulation rates of $\mathrm{C}$ could be the relatively low sediment discharge from terrestrial sources 
https://doi.org/10.5194/bg-2021-157

Preprint. Discussion started: 8 July 2021

(c) Author(s) 2021. CC BY 4.0 License.

(c) (i)

415 such as the Kennedy River (Nuwer and Kiel, 2005). Previous work in Clayoquot Sound attributed low carbon accumulation rates in eelgrass, in part, to relatively clear waters (secchi disc measurements) and $\mathrm{C} / \mathrm{N}$ ratios that reflect marine rather than terrestrial sediment contributions (Postlethwaite et al. 2018).

A third important feature of the Clayoquot Sound marshes is that the region is experiencing vertical land motion that counteracts the effects of sea level rise (Mazzotti et al. 2007, 2008; Montillet et al. 2018). Previous work suggests that, in 420 many cases, marshes are responding to rising sea levels by migrating inland (Kirwan et al. 2016). In contrast, in our study region the nearby town of Tofino experiences uplift of $2.86 \mathrm{~mm} \mathrm{y}^{-1}$, such that relative sea level is dropping by $1.08-1.15 \mathrm{~mm}$ $\mathrm{y}^{-1}$ (Montillet et al. 2018). Recent work along the Oregon coast suggests that relative sea level rise is a dominant control on vertical accretion rates in tidal marsh systems, and areas experiencing negative sea level rise (or land uplift) have the lowest rates of $\mathrm{C}$ accumulation (Peck et al. 2020). The negative sea level rise and relatively low $\mathrm{C}$ accumulation rates, particularly

425 in the low marsh settings of Clayoquot Sound and Pacific Rim National Park, are consistent with this result.

A final discriminating characteristic between the high and low marsh cores in Clayoquot Sound are the ${ }^{210} \mathrm{~Pb}$ inventories (Fig. A3), which suggest that the high and low marsh zones are subjected to different erosional processes. Given that these cores all come from the same area one would assume that all the cores should have similar inputs of ${ }^{210} \mathrm{~Pb}$ (Olid et al. 2010; Arias-Ortiz et al. 2018). However, a comparison of the ${ }^{210} \mathrm{~Pb}$ inventories shows that the high marshes accumulate much more

$430{ }^{210} \mathrm{~Pb}$ than the low marshes. This difference, together with the lower concentrations of the ${ }^{210} \mathrm{~Pb}$ in the upper layers of the low marsh cores, could result from focusing / humus formation causing greater ${ }^{210} \mathrm{~Pb}$ accumulation in the high marshes and/or reduced accumulation in the low marshes due to erosion and winnowing processes. One possible explanation here is that the extensive, shallow flats in the low marsh regions of Clayoquot Sound are subjected to more intensive tidal erosion and therefore removal of humus material, which results in lower accumulation rates relative to the high marsh zones. Further 435 studies are needed to estimate the significance of these drivers within the region. 
https://doi.org/10.5194/bg-2021-157

Preprint. Discussion started: 8 July 2021

(c) Author(s) 2021. CC BY 4.0 License.
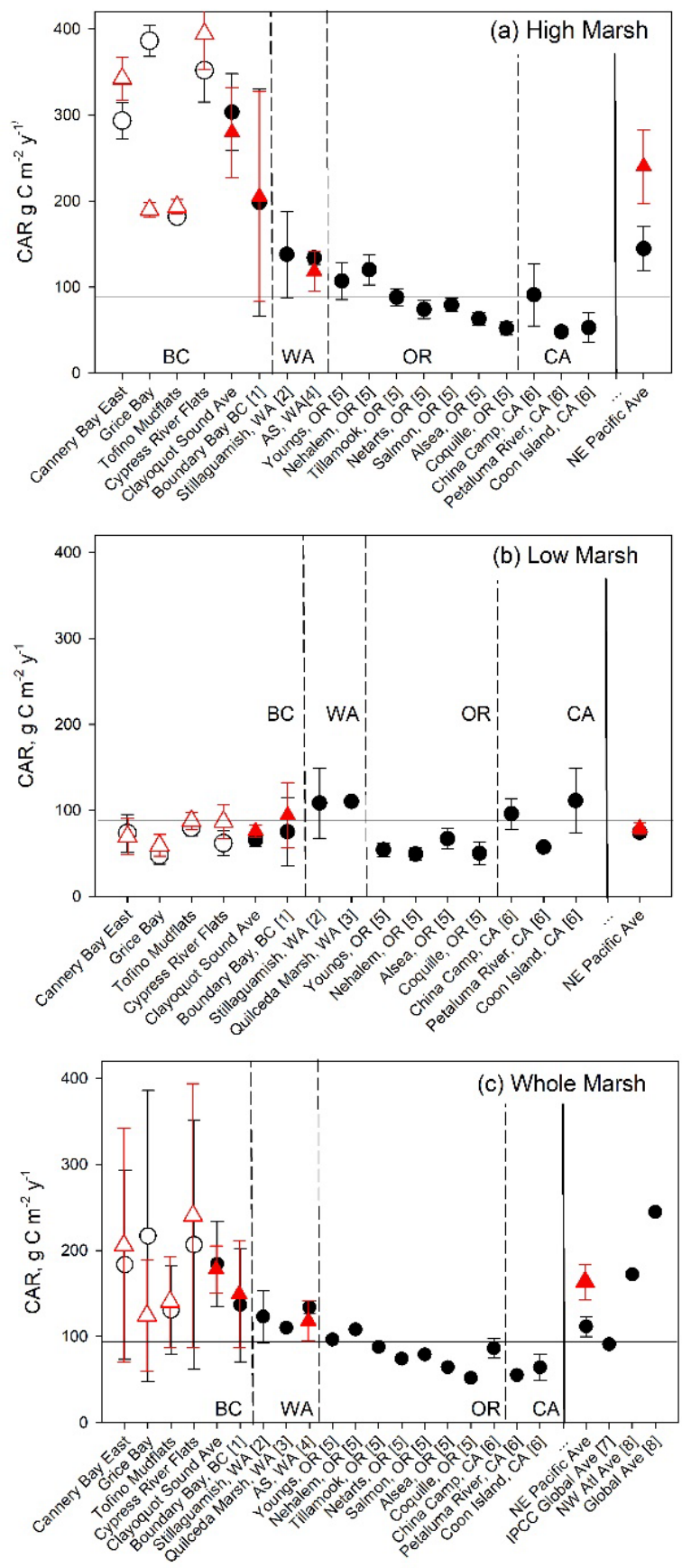

Figure 7. Comparison of Clayoquot Sound CARs with other salt marshes with ${ }^{210} \mathrm{~Pb}$ dating, for whole core (black circles) and 30year (red triangle) estimates. Individual Clayoquot Sound marshes are indicated with open symbols followed by a regional mean ( \pm SE). Additional site data taken from: [1] Boundary Bay, BC, Canada (Gailis et al., 2021); [2] Stillaguamish, WA, USA (Poppe and Ryczik, 2019); [3] Snohomish Estuary, WA, USA (Crooks et al., 2014); [4] Animal Slough (AS) in southern Puget Sound, WA, USA (Note that red triangle is 50-yr average; Drexler et al., 2019); [5] coastal OR, USA (Peck et al., 2020); [6] San Fransciso Bay, CA, USA (Callaway et al., 2012). Global and other regional averages are taken from [7] IPCC (2013) and [8] Ouyang and Lee (2014); only a fraction of data $(<10 \%)$ in $[8]$ were dated using ${ }^{210} \mathrm{~Pb}$. Horizontal line represents IPCC (2013) global average. 
https://doi.org/10.5194/bg-2021-157

Preprint. Discussion started: 8 July 2021

(c) Author(s) 2021. CC BY 4.0 License.

(c) (i)

\section{.3. Comparison of Whole-Core and 30-year CARs}

Estimating CARs to a consistent age horizon of 30 years allowed us to compare $\mathrm{C}$ accumulation between marshes and marsh zones, but it also reveals interesting information about differences in CAR depending on the approach used to estimate these values. Previous comparisons in nearby Boundary Bay marsh showed that CARs were $20 \%$ higher during the last 30 years when compared to the whole core estimates (Gailis et al. 2021). Because $\% \mathrm{C}$ decreases with depth in all 34 cores from Clayoquot Sound, we might anticipate that CARs for the most recent years will always result in a higher CAR than a measurement of $\mathrm{C}$ stock to the depth of minimum ${ }^{210} \mathrm{~Pb}$ detectable activity. This can be partially attributed to remineralization of soil $\mathrm{C}$ over time, which would decrease overall $\% \mathrm{C}$ in the deeper portions of the sediment cores (Callaway et al. 2012; Johannessen and MacDonald 2016). In Clayoquot Sound, however, the CARs estimated for the last 30 years were not substantially different from our estimates made to the base of the peat layer (Table 2), particularly in the high marsh zone where the average age for the base of the peat layer was $33 \pm 9$ years. Slightly larger differences were seen in the slowly-accumulating low marsh zones, where the 30-year CAR was about $15 \%$ higher. Overall, the young ages of these marshes result in small differences between the two estimates.

The examination of 30-year CARs as well as CARs in relatively young marshes could have interesting implications for future blue $\mathrm{C}$ assessments. Many marsh restoration projects in which $\mathrm{C}$ is being measured are currently on time scales of 10 to 30 years past the initiation of restoration (e.g. Abbott et al. 2019; Drexler et al. 2019). Vegetational succession and C storage in a restored tidal marsh can take over 10 years (Havens et al., 2002; Craft et al. 2003), and even a 30-year monitoring period would capture a period of gradually improving $\mathrm{C}$ sequestration potential in restored tidal marsh soils (e.g. Howe et al. 2009). However, the inflation of CARs in younger sediments in the Clayoquot Sound and Boundary Bay sediments could provide a caution that CARs measured from relatively young marker horizons are at risk of overestimating total $\mathrm{C}$ in sediments, especially if these CARs are used to project $\mathrm{C}$ sequestration over longer time periods. Several recent studies have shown substantially higher CARs in restored vs natural marshes after approximately 10 years (e.g., Poppe and Rybczyk, 2019; Drexler et al. 2019). The causes of these inflated CARs can be very site-specific, depending on the types of colonizing vegetation (Kelleway et al. 2017) and the relative contributions of allochthonous mineral materials (Drexler et al., 2019). In the case of Clayoquot Sound, it is possible that these high CARs will be sustained, making this marsh extremely important as a regional $\mathrm{C}$ sink. However, we also cannot rule out the possibility that longer-term processes, such as remineralization and sediment redistribution, could reduce the actual amount of $\mathrm{C}$ stored as the marshes age, such that the accumulation rates become more comparable to those found on other parts of the Pacific coast (Fig. 7).

\subsection{Comparison with carbon storage in boreal forest ecosystems}

The relevance of blue $\mathrm{C}$ storage potential to climate change mitigation depends on the scale over which it is considered. In the literature, the carbon accumulation potential of blue carbon is often compared with terrestrial ecosystems, and it is often stated that, per unit area, blue $\mathrm{C}$ ecosystems accumulate carbon at higher estimated rates than terrestrial forest soils (McLeod 
https://doi.org/10.5194/bg-2021-157

Preprint. Discussion started: 8 July 2021

(c) Author(s) 2021. CC BY 4.0 License.

et al. 2011). A first-order comparison for Canadian ecosystems shows the same pattern of higher carbon uptake rates per unit area in tidal wetlands when compared with net ecosystem productivity of terrestrial forests. Forested areas in Canada are estimated to take up carbon at rates ranging from $35 \mathrm{~g} \mathrm{C} \mathrm{m}^{-2} \mathrm{yr}^{-1}$ (Canada-wide estimate, Stinson et al., 2011) to $63 \mathrm{~g} \mathrm{C} \mathrm{m}^{-2}$ $\mathrm{yr}^{-1}$ (British Columbia, Peng et al., 2014). The 30-year CAR for salt marshes in Clayoquot Sound are approximately 2-7 times higher, averaging $178 \pm 46 \mathrm{~g} \mathrm{C} \mathrm{m}^{-2} \mathrm{yr}^{-1}$. (Note that we considered forests' net ecosystem productivity, which is higher than $\mathrm{C}$ uptake rates of $4.6 \pm 2.1 \mathrm{~g} \mathrm{C} \mathrm{m}^{-2} \mathrm{yr}^{-1}$ for boreal forest soils cited by McLeod et al., 2011).

However, consideration of the areal extent of each of these ecosystems is extremely important for contextualizing blue $\mathrm{C}$ uptake among Canadian ecosystems. Estimates of total salt marsh area in Canada range from 44,000 ha (Bridgham et al., 2006) to 111,274 ha (Mcowen et al., 2017). In contrast, the boreal forest ecosystem is one of Canada's largest terrestrial 485 biomes and encompasses approximately 270 million ha (Kurz et al. 2013). Our Clayoquot Sound data represent only a small area of a single region of the west coast, but if we assume our CAR estimate of $184 \pm 50 \mathrm{~g} \mathrm{C} \mathrm{m}^{-2} \mathrm{yr}^{-1}$ from Clayoquot Sound approximates the average for all tidal salt marshes in Canada, Canada's marshes would accumulate somewhere between

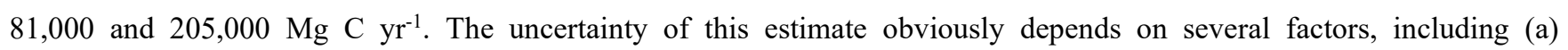
uncertainties in the pan-Canadian average for CARs which will be affected by several processes; and (b) large uncertainties associated with the areal extent of salt marshes. However, even with this large range, this annual carbon accumulation from Canadian salt marshes is between 0.4 and $2.9 \%$ of the carbon estimated to accumulate annually by Canadian boreal forests $\left(6,750,000-18,090,000 \mathrm{Mg} \mathrm{C} \mathrm{yr}^{-1}\right)$.

This rough calculation reveals three important points. The first is that regional-to-global estimates of blue $\mathrm{C}$ accumulation rates depend on regionally specific measurements of salt marsh $\mathrm{C}$ stocks and accumulation rates. Extrapolation of blue $\mathrm{C}$ 495 accumulation rates based on globally derived averages (or averages from regions other than the one in question) can lead to large uncertainties in blue $\mathrm{C}$ accumulation rates. Second, in addition to the regionally-specific nature of processes controlling blue $\mathrm{C}$ accumulation, we note that estimation of the areal extent of these marshes varies by an order of magnitude within Canada alone, and determinations of the relative proportions and high-to-low marsh settings have not been quantified. Estimation of blue $\mathrm{C}$ potential in policy-specific contexts requires a more detailed determination of the areal extent of these marshes, especially when considering provincial-to-national scales. Finally, we posit that the small area over which blue $\mathrm{C}$ accumulates likely influences the scale over which it is best considered for natural land carbon sequestration and accounting. Blue $\mathrm{C}$ accumulation occurs in only $0.016-0.1 \%$ the land area of boreal forests nationwide. On a global, national, and even provincial scale, total blue $\mathrm{C}$ sequestration in salt marshes is relatively small compared to the large areal expanses of forest. However, the very high, per-unit area sequestration of carbon in salt marsh ecosystems can increase its importance at localto-regional scales and should be considered as an important co-benefit to restoration activities and conservation for other purposes. 
https://doi.org/10.5194/bg-2021-157

Preprint. Discussion started: 8 July 2021

(c) Author(s) 2021. CC BY 4.0 License.

(c) (i)

\subsection{Future Work}

While this study has provided a useful first step in quantifying blue $\mathrm{C}$ stocks, storage, and accumulation rates, we note the following considerations in estimating the potential of blue $\mathrm{C}$ within this region. First, our study has estimated blue $\mathrm{C}$ in 47 ha of high and low marsh areas of Clayoquot Sound. We expect that these mesotidal estuarine marshes, often constrained in size by surrounding topography, are typical of the marshes found on the Pacific coast of British Columbia, the total estimated area of which is 60 square kilometres, or 6000 ha (Ryder et al. 2007). However, given variability in riverine discharge and tectonic settings along the coast, we anticipate that additional measurements (additional marshes, with differing riverine and sedimentary inputs, and variable uplift setting) will be necessary to understand the variability in carbon accumulation along the Pacific Coast of Canada. Second, our study has focused on estimation of carbon stocks and accumulation rates within these marshes, and full estimation of blue $\mathrm{C}$ potential will ultimately require estimation of greenhouse gas fluxes of carbon dioxide, methane, and nitrous oxide within these marshes (e.g. Chmura et al. 2011). The mesotidal nature of some of these marsh locations could mean that some of these marshes emit substantial contributions of methane, which may counter their effects as C sinks (Poffenbarger et al. 2011). Finally, this study has revealed the importance of classifying high vs low marsh zones to best quantify carbon stocks and accumulation rates, as the different vegetation growth and sedimentary processes operating in these zones can critically influence CARs, and therefore estimates of $\mathrm{C}$ sequestration. Future work thus needs to involve better quantification of the areal extent and classification of salt marshes, both within Clayoquot Sound, along the Pacific coast, and in Canada as a whole.

\section{Conclusion}

525 Our work helps address the data gap for North American blue $\mathrm{C}$ by producing CAR estimates using ${ }^{210} \mathrm{~Pb}$-derived mass accumulation rates of salt marsh sediments, showing CAR comparable to other salt marsh locations in the Northeast Pacific coast. Importantly, this work demonstrates that the marshes of Clayoquot Sound along the Pacific Coast of Canada exhibit substantially smaller $\mathrm{C}$ stocks when compared with other regional salt marshes to the south, along the Pacific Coast of the United States. We attribute these lower stocks to substantially shallower $(<50 \mathrm{~cm})$ depths of marsh initiation in all high and

530 low marsh settings. At the same time, while carbon stocks are lower than regional and global averages, the rates of carbon accumulation in these marshes are comparable and even higher than regional estimates. We show that both 30-year CARs and CARs estimated to the peat base are substantially greater than regional averages generated using only ${ }^{210} \mathrm{~Pb}$-derived mass accumulation rates. However, significant variability exists between marshes, and different radioisotope dating methods in CAR measurement create uncertainty. Our results support existing findings that blue $\mathrm{C}$ soils accumulate carbon at high rates,

535 limited only by the spatial extent of such ecosystems. These results provide a natural analogue for monitoring carbon accretion over timescales relevant for restoration activities. 


\section{Appendix A Supplemental Tables and Figures}

Table A1. Core Locations, Soil Carbon Characteristics, and Carbon Stocks

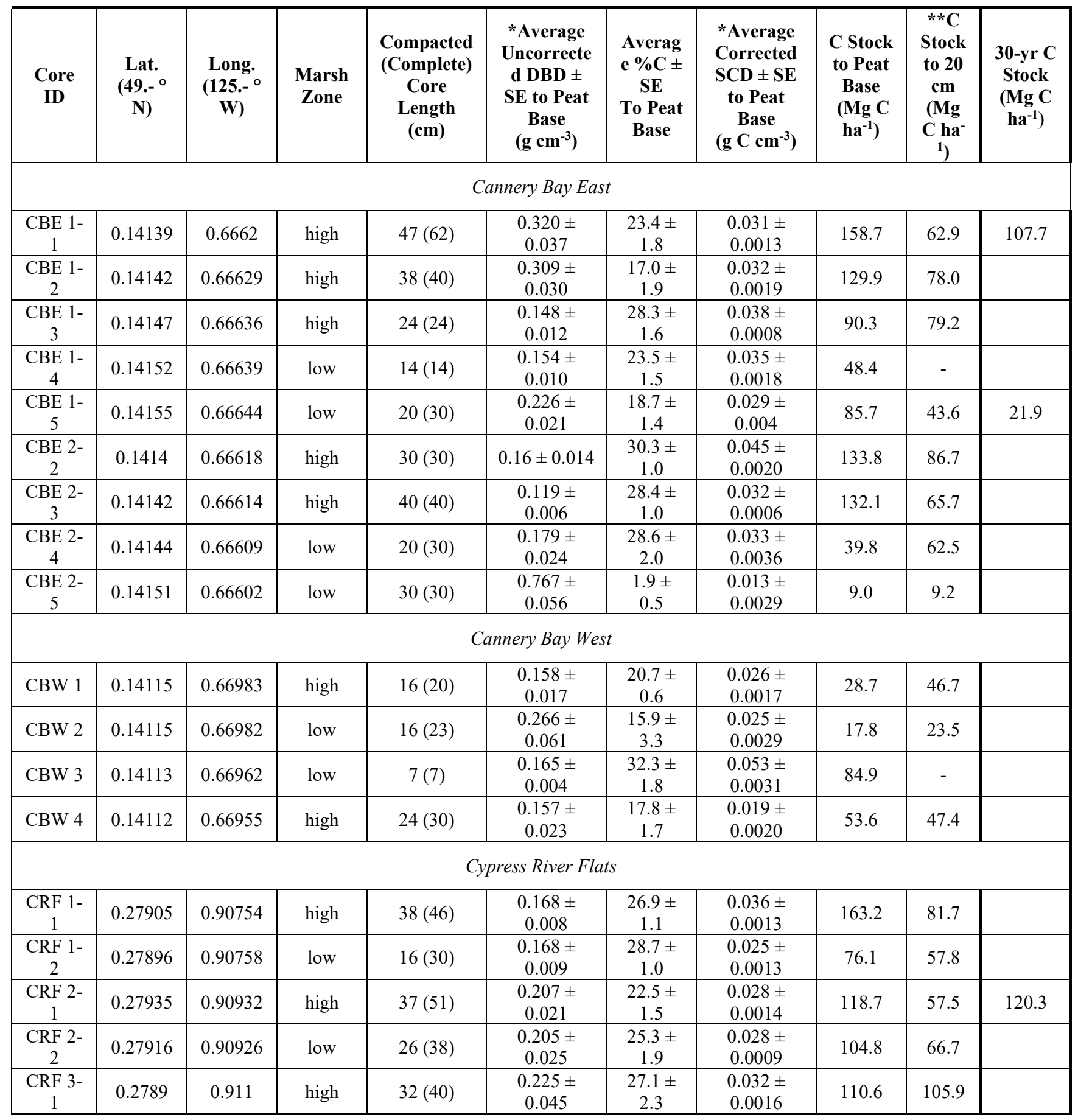




\begin{tabular}{|c|c|c|c|c|c|c|c|c|c|c|}
\hline $\begin{array}{c}\text { Core } \\
\text { ID }\end{array}$ & $\begin{array}{l}\text { Lat. } \\
\left(49 .-^{\circ}\right. \\
\text { N) }\end{array}$ & $\begin{array}{l}\text { Long. } \\
\text { (125.- } \\
\text { W) }\end{array}$ & $\begin{array}{c}\text { Marsh } \\
\text { Zone }\end{array}$ & $\begin{array}{c}\text { Compacted } \\
\text { (Complete) } \\
\text { Core } \\
\text { Length } \\
\text { (cm) }\end{array}$ & $\begin{array}{c}\text { *Average } \\
\text { Uncorrecte } \\
\text { d DBD } \pm \\
\text { SE to Peat } \\
\text { Base } \\
\left(\mathrm{g} \mathrm{cm}^{-3}\right)\end{array}$ & $\begin{array}{c}\text { Averag } \\
\text { e } \% C \pm \\
\text { SE } \\
\text { To Peat } \\
\text { Base }\end{array}$ & $\begin{array}{c}\text { *Average } \\
\text { Corrected } \\
\text { SCD } \pm \text { SE } \\
\text { to Peat } \\
\text { Base } \\
\left(\mathrm{g} \mathrm{C} \mathrm{cm}^{-3}\right)\end{array}$ & $\begin{array}{c}\text { C Stock } \\
\text { to Peat } \\
\text { Base } \\
\left(\mathrm{Mg} \mathrm{C}^{-1}\right. \\
\left.\mathrm{ha}^{-1}\right)\end{array}$ & $\begin{array}{c}* * \mathrm{C} \\
\text { Stock } \\
\text { to } 20 \\
\text { cm } \\
(\mathrm{Mg} \\
\mathrm{C} \mathrm{ha} \\
{ }_{1}\end{array}$ & $\begin{array}{c}\text { 30-yr C } \\
\text { Stock } \\
(\mathrm{Mg} \mathrm{C} \\
\left.\mathrm{ha}^{-1}\right)\end{array}$ \\
\hline $\begin{array}{c}\text { CRF } 3- \\
2 \\
\end{array}$ & 0.27882 & 0.91087 & low & $23(30)$ & $\begin{array}{c}0.192 \pm \\
0.023 \\
\end{array}$ & $\begin{array}{c}27.4 \pm \\
2.3 \\
\end{array}$ & $\begin{array}{c}0.035 \pm \\
0.0021 \\
\end{array}$ & 85.8 & 94.8 & 27.2 \\
\hline \multicolumn{11}{|c|}{ Grice Bay - Kootowis Creek } \\
\hline $\begin{array}{c}\text { GBK 1- } \\
1\end{array}$ & 0.08754 & 0.73238 & high & $16(31)^{* * *}$ & $\begin{array}{c}0.232 \pm \\
0.032\end{array}$ & $\begin{array}{c}18.3 \pm \\
2.3\end{array}$ & $\begin{array}{c}0.016 \pm \\
0.0012\end{array}$ & 41.0 & 35.2 & \\
\hline $\begin{array}{c}\text { GBK 1- } \\
2\end{array}$ & 0.08756 & 0.73261 & high & $19(32) * * *$ & $\begin{array}{c}0.440 \pm \\
0.060\end{array}$ & $\begin{array}{c}10.0 \pm \\
1.8\end{array}$ & $\begin{array}{c}0.015 \pm \\
0.0016\end{array}$ & 51.2 & 40.0 & 59.2 \\
\hline $\begin{array}{c}\text { GBK 1- } \\
3\end{array}$ & 0.08763 & 0.73271 & high & $23(26)^{* * *}$ & $\begin{array}{c}0.257 \pm \\
0.027\end{array}$ & $\begin{array}{c}15.7 \pm \\
1.4\end{array}$ & $\begin{array}{c}0.032 \pm \\
0.0028\end{array}$ & 60.9 & 64.5 & \\
\hline $\begin{array}{c}\text { GBK 1- } \\
4\end{array}$ & 0.08771 & 0.73283 & low & $13(20)^{* * *}$ & $\begin{array}{c}0.298 \pm \\
0.017\end{array}$ & $\begin{array}{c}12.0 \pm \\
0.8 \\
\end{array}$ & $\begin{array}{c}0.023 \pm \\
0.0009\end{array}$ & 41.6 & 41.6 & 19.1 \\
\hline \multicolumn{11}{|c|}{ Kennedy Cove South } \\
\hline $\begin{array}{c}\text { KCS 1- } \\
1\end{array}$ & 0.13696 & 0.67082 & high & $24(31)$ & $\begin{array}{c}0.227 \pm \\
0.041\end{array}$ & $\begin{array}{c}21.4 \pm \\
2.1\end{array}$ & $\begin{array}{c}0.030 \pm \\
0.0045\end{array}$ & 66.2 & 66.2 & \\
\hline $\begin{array}{c}\text { KCS 1- } \\
2\end{array}$ & 0.13707 & 0.67085 & low & $14(21)$ & $\begin{array}{c}0.248 \pm \\
0.074\end{array}$ & $\begin{array}{c}15.0 \pm \\
6.9\end{array}$ & $\begin{array}{c}0.018 \pm \\
0.0012\end{array}$ & 27.4 & - & \\
\hline $\begin{array}{c}\text { KCS 1- } \\
3 \\
\end{array}$ & 0.13714 & 0.67093 & low & $16(36)$ & $\begin{array}{c}0.427 \pm \\
0.097 \\
\end{array}$ & $\begin{array}{c}11.1 \pm \\
9.5 \\
\end{array}$ & $\begin{array}{c}0.009 \pm \\
0.0016\end{array}$ & 25.6 & 24.0 & \\
\hline $\begin{array}{c}\text { KCS 1- } \\
4\end{array}$ & 0.13719 & 0.67096 & low & $10(20)$ & $\begin{array}{c}0.296 \pm \\
0.085\end{array}$ & $\begin{array}{c}14.7 \pm \\
2.2\end{array}$ & $\begin{array}{c}0.014 \pm \\
0.0012\end{array}$ & 28.9 & 28.9 & \\
\hline $\begin{array}{c}\text { KCS 1- } \\
5\end{array}$ & 0.1372 & 0.67107 & low & $10(12)$ & $\begin{array}{c}0.509 \pm \\
0.125\end{array}$ & $\begin{array}{c}7.6 \pm \\
2.1\end{array}$ & $\begin{array}{c}0.015 \pm \\
0.0029\end{array}$ & 17.8 & 17.8 & \\
\hline \multicolumn{11}{|c|}{ Shipwreck Cove } \\
\hline $\begin{array}{c}\text { SWC 1- } \\
1\end{array}$ & 0.12995 & 0.69943 & high & $29(29)$ & $\begin{array}{c}0.248 \pm \\
0.093\end{array}$ & $\begin{array}{c}27.6 \pm \\
3.4 \\
\end{array}$ & $\begin{array}{c}0.033 \pm \\
0.0030\end{array}$ & 42.3 & 43.9 & \\
\hline $\begin{array}{c}\text { SWC 2- } \\
1\end{array}$ & 0.13014 & 0.69908 & high & $18(20)$ & $\begin{array}{c}0.541 \pm \\
0.124\end{array}$ & $\begin{array}{c}21.0 \pm \\
2.6\end{array}$ & $\begin{array}{c}0.067 \pm \\
0.0093\end{array}$ & 133.4 & 133.4 & \\
\hline \multicolumn{11}{|c|}{ Tofino Mud Flats } \\
\hline $\begin{array}{c}\text { TMF 1- } \\
1 \\
\end{array}$ & 0.13014 & 0.88689 & high & $27(45)$ & $\begin{array}{c}0.326 \pm \\
0.068 \\
\end{array}$ & $\begin{array}{c}18.6 \pm \\
3.4 \\
\end{array}$ & $\begin{array}{c}0.019 \pm \\
0.0012 \\
\end{array}$ & 45.4 & 42.8 & \\
\hline $\begin{array}{c}\text { TMF 1- } \\
2\end{array}$ & 0.1302 & 0.88688 & low & $26(30)$ & $\begin{array}{c}0.241 \pm \\
0.008\end{array}$ & $\begin{array}{c}14.0 \pm \\
0.8 \\
\end{array}$ & $\begin{array}{c}0.038 \pm \\
0.0012\end{array}$ & 53.0 & 57.5 & 28.9 \\
\hline $\begin{array}{c}\text { TMF 2- } \\
1\end{array}$ & 0.12989 & 0.88661 & high & $28(31)$ & $\begin{array}{c}0.751 \pm \\
0.066 \\
\end{array}$ & $\begin{array}{c}5.6 \pm \\
1.5 \\
\end{array}$ & $\begin{array}{c}0.022 \pm \\
0.0041\end{array}$ & 62.4 & 61.0 & 61.5 \\
\hline $\begin{array}{c}\text { TMF 2- } \\
2\end{array}$ & 0.13017 & 0.88665 & low & $27(30)$ & $\begin{array}{c}0.231 \pm \\
0.010\end{array}$ & $\begin{array}{c}17.2 \pm \\
0.7\end{array}$ & $\begin{array}{c}0.035 \pm \\
0.0010\end{array}$ & 65.9 & 69.5 & \\
\hline
\end{tabular}

*Ave DBD values were not corrected for compaction (see Table A3 for corrected DBDs), but SCD values have been corrected for compaction.

** Cores that do not extend to $20 \mathrm{~cm}$ and do not penetrate a sand/gravel/clay layer at the base were excluded from the $20 \mathrm{~cm}$ calculation.

$* * *$ GBK cores were extracted using a steel sledge corer that penetrated $15-30 \mathrm{~cm}$ into the sand and clay layers. The total core lengths were 46 (88), 60 (100), 59 (66) and 24 (37) cm for GBK 1-1,1-2, 1-3, and 1-4, respectively. Depths provided here are just

below the transition from peat to sand, two $\mathrm{cm}$ into the minimal $\% \mathrm{C}$ layer. 
https://doi.org/10.5194/bg-2021-157

Preprint. Discussion started: 8 July 2021

(c) Author(s) 2021. CC BY 4.0 License.

Table A2. Downcore distribution of ${ }^{210} \mathrm{~Pb}$ and ${ }^{226} \mathrm{Ra}$ in eight cores used for ${ }^{210} \mathrm{~Pb}$ dating.

\begin{tabular}{|c|c|c|c|c|c|c|c|c|c|}
\hline $\begin{array}{l}\text { Upper } \\
\text { Depth } \\
\text { (cm) }\end{array}$ & $\begin{array}{c}\text { Sediment } \\
\text { Type }\end{array}$ & $\begin{array}{c}\text { Supported } \\
{ }^{210} \mathrm{~Pb}\left({ }^{226} \mathrm{Ra}\right. \\
\mathrm{Bq} / \mathrm{kg})\end{array}$ & $\begin{array}{c}{ }^{210} \mathrm{~Pb} \text { total } \\
(\mathrm{Bq} / \mathrm{kg})\end{array}$ & $\begin{array}{c}+/-1 \text { SD } \\
(\mathrm{Bq} / \mathbf{k g})\end{array}$ & $\begin{array}{l}{ }^{210} \mathrm{~Pb}_{\text {exs }} \\
(\mathrm{Bq} / \mathrm{kq})\end{array}$ & $\begin{array}{c}+/-1 \text { SD } \\
(\mathrm{Bq} / \mathbf{k g})\end{array}$ & Slope $\left(\mathrm{cm}^{2} / \mathrm{g}\right)$ & $\begin{array}{c}\text { Age (yr } \\
\text { before } \\
2016)\end{array}$ & $\begin{array}{c}\text { Age SD } \\
(\mathrm{yr})\end{array}$ \\
\hline \multicolumn{10}{|c|}{ CBE 1-1 (HM) ${ }^{\mathrm{a}}$} \\
\hline 0 & humus & 2.03 & 196.2 & 7.2 & 194.2 & 7.2 & $0.20 \pm 0.014$ & 0.51 & 0.04 \\
\hline 4 & humus & 2.03 & 187.6 & 7.1 & 185.6 & 7.1 & & 2.70 & 0.19 \\
\hline 5 & humus & 2.03 & 245.7 & 9.4 & 243.7 & 9.4 & & 3.27 & 0.24 \\
\hline 6 & humus & 2.03 & 172.5 & 6.8 & 170.5 & 6.8 & & 3.79 & 0.27 \\
\hline 7 & peat & 2.03 & 158.5 & 6.5 & 156.5 & 6.5 & & 4.43 & 0.32 \\
\hline 8 & peat & 2.03 & 149.1 & 6.3 & 147.0 & 6.3 & & 5.14 & 0.37 \\
\hline 10 & peat & 2.03 & 137.4 & 6.0 & 135.3 & 6.0 & & 6.68 & 0.48 \\
\hline 11 & peat & 2.03 & 124.2 & 5.5 & 122.2 & 5.5 & & 7.38 & 0.53 \\
\hline 13 & peat & 2.03 & 112.7 & 5.2 & 110.7 & 5.3 & & 9.12 & 0.66 \\
\hline 16 & peat & 2.03 & 102.5 & 4.8 & 100.4 & 4.8 & & 12.33 & 0.89 \\
\hline 21 & peat & 2.03 & 86.2 & 4.5 & 84.2 & 4.5 & & 21.57 & 1.55 \\
\hline 24 & peat & 2.03 & 76.3 & 4.1 & 74.3 & 4.1 & & 29.21 & 2.10 \\
\hline $25 *$ & peat & 2.03 & & & & & & 31.5 & 2.27 \\
\hline 27 & peat & 2.03 & 62.0 & 3.8 & 59.9 & 3.8 & & 35.31 & 2.54 \\
\hline 32 & peat & 2.03 & 53.5 & 3.6 & 51.4 & 3.6 & & 44.37 & 3.19 \\
\hline 34 & peat & 2.03 & 46.6 & 3.2 & 44.6 & 3.2 & & 47.51 & 3.42 \\
\hline 37 & peat & 2.03 & 36.7 & 2.8 & 34.7 & 2.8 & & 51.56 & 3.71 \\
\hline $38 * *$ & peat & 2.03 & & & & & & 54.1 & 3.90 \\
\hline 42 & sand & 2.03 & 28.1 & 2.6 & 26.0 & 2.7 & & & \\
\hline 46 & sand & 2.03 & 24.6 & 0.5 & 22.6 & 0.5 & & & \\
\hline $\begin{array}{c}14 \\
(226 \mathrm{Ra})\end{array}$ & & 1.90 & & 0.55 & & & & & \\
\hline $\begin{array}{c}44 \\
\left({ }^{226} \mathrm{Ra}\right)\end{array}$ & & 2.16 & & 0.46 & & & & & \\
\hline
\end{tabular}

CBE 1-5 (LM)

$\begin{array}{cccccccccc}0 & \text { humus+peat } & 1.74 & 374.0 & 9.5 & 372.2 & 9.5 & 0.90 \pm 0.30 & 4.04 & 1.21 \\ 3 & \text { humus+peat } & 1.74 & 322.3 & 9.8 & 320.5 & 9.9 & \mathbf{5 . 1} & 16.46 & 4.93 \\ \mathbf{6}^{*} & \text { humus+peat } & \mathbf{1 . 7 4} & \mathbf{8 3 . 9} & \mathbf{5 . 1} & \mathbf{8 2 . 2} & \mathbf{5 . 1} & \mathbf{3 1 . 7 7} & \mathbf{9 . 5 2} \\ 10 & \text { humus+peat } & 1.74 & 19.2 & 2.0 & 17.4 & 2.1 & 58.04 & 17.39 \\ 14 & \text { humus+peat } & 1.74 & 12.7 & 1.9 & 11.0 & 2.0 & 79.12 & 23.70 \\ 18 & \text { humus+peat } & 1.74 & 20.7 & 2.2 & 19.0 & 2.2 & 118.11 & 35.38\end{array}$


https://doi.org/10.5194/bg-2021-157

Preprint. Discussion started: 8 July 2021

(c) Author(s) 2021. CC BY 4.0 License.

\begin{tabular}{|c|c|c|c|c|c|c|c|c|c|}
\hline $\begin{array}{l}\text { Upper } \\
\text { Depth } \\
\text { (cm) }\end{array}$ & $\begin{array}{c}\text { Sediment } \\
\text { Type }\end{array}$ & $\begin{array}{c}\text { Supported } \\
{ }^{210} \mathrm{~Pb}\left({ }^{226} \mathrm{Ra},\right. \\
\mathrm{Bq} / \mathrm{kg})\end{array}$ & $\begin{array}{c}{ }^{210} \mathrm{~Pb} \text { total } \\
(\mathrm{Bq} / \mathrm{kg})\end{array}$ & $\begin{array}{l}+/-1 \mathrm{SD} \\
(\mathrm{Bq} / \mathbf{k g})\end{array}$ & $\begin{array}{l}{ }^{210} \mathrm{~Pb}_{\text {exs }} \\
(\mathrm{Bq} / \mathrm{kq})\end{array}$ & $\begin{array}{l}+/-1 \mathrm{SD} \\
(\mathrm{Bq} / \mathbf{k g})\end{array}$ & Slope $\left(\mathrm{cm}^{2} / \mathrm{g}\right)$ & $\begin{array}{c}\text { Age (yr } \\
\text { before } \\
\text { 2016) }\end{array}$ & $\begin{array}{c}\text { Age SD } \\
(y \mathbf{r})\end{array}$ \\
\hline $19 * *$ & humus + peat & 1.74 & & & & & & 131.39 & 39.36 \\
\hline $6\left({ }^{226} \mathrm{Ra}\right)$ & & 1.38 & & 0.94 & & & & & \\
\hline $\begin{array}{c}18 \\
\left({ }^{226} \mathrm{Ra}\right)\end{array}$ & & 2.10 & & 0.46 & & & & & \\
\hline
\end{tabular}

\section{CRF 2-1 (HM) ${ }^{a}$}

\begin{tabular}{|c|c|c|c|c|c|c|c|c|c|}
\hline 0 & humus & 1.58 & 225.2 & 17.5 & 223.6 & 17.5 & $0.13 \pm 0.013$ & 0.33 & 0.03 \\
\hline 4 & humus & 1.58 & 194.2 & 16.4 & 192.6 & 16.4 & & 1.86 & 0.19 \\
\hline 8 & humus & 1.58 & 169.3 & 15.4 & 167.7 & 15.4 & & 3.44 & 0.36 \\
\hline 13 & peat & 1.58 & 149.3 & 14.5 & 147.8 & 14.5 & & 7.20 & 0.75 \\
\hline 16 & peat & 1.58 & 129.9 & 13.7 & 128.4 & 13.8 & & 10.23 & 1.07 \\
\hline 19 & peat & 1.58 & 114.1 & 12.9 & 112.5 & 13.0 & & 13.58 & 1.42 \\
\hline 22 & peat & 1.58 & 101.1 & 12.0 & 99.5 & 12.0 & & 16.27 & 1.70 \\
\hline 25 & peat & 1.58 & 91.8 & 11.4 & 90.2 & 11.5 & & 18.84 & 1.97 \\
\hline 28 & peat & 1.58 & 80.0 & 11.1 & 78.4 & 11.1 & & 22.36 & 2.33 \\
\hline $30 * *$ & sand+peat & & & & & & & 26.7 & 2.79 \\
\hline $31 *$ & sand & 1.58 & 72.1 & 10.2 & 70.5 & 10.3 & & 30.52 & 3.18 \\
\hline 34 & sand & 1.58 & 61.6 & 9.7 & 60.1 & 9.8 & & & \\
\hline \multicolumn{10}{|c|}{ CRF 3-2 (LM) ${ }^{b}$} \\
\hline 1 & humus+peat & 1.58 & 326.6 & 14.3 & 325.0 & 14.4 & $1.19 \pm 0.28$ & 9.93 & 2.31 \\
\hline 4 & peat & 1.58 & 212.6 & 7.1 & 211.0 & 7.2 & & 27.89 & 6.50 \\
\hline $5 *$ & peat & & & & & & & 31.3 & 7.30 \\
\hline 8 & peat & 1.58 & 182.8 & 7.5 & 181.2 & 7.6 & & 44.70 & 10.42 \\
\hline 11 & peat & 1.58 & 130.5 & 5.6 & 129.0 & 5.7 & & 61.90 & 14.42 \\
\hline 14 & peat & 1.58 & 27.0 & 2.5 & 25.5 & 2.8 & & 85.20 & 19.85 \\
\hline $18 * *$ & peat & & & & & & & 139.5 & 32.49 \\
\hline 20 & peat + sand & 1.58 & 2.2 & 1.2 & & & & & \\
\hline $8\left({ }^{226} \mathrm{Ra}\right)$ & & 2.50 & & 1.17 & & & & & \\
\hline $\begin{array}{c}14 \\
\left({ }^{226} \mathrm{Ra}\right)\end{array}$ & & 0.67 & & 0.67 & & & & & \\
\hline
\end{tabular}

\section{GBK 1-2 (HM) ${ }^{\text {a }}$}

\begin{tabular}{|c|c|c|c|c|c|c|c|}
\hline humus & 2.63 & 191.6 & 7.1 & 189.0 & 7.1 & $0.045 \pm 0.0021$ & 0.24 \\
\hline humus+peat & 2.63 & 183.0 & 7.0 & 180.3 & 7.0 & & 1.20 \\
\hline
\end{tabular}


https://doi.org/10.5194/bg-2021-157

Preprint. Discussion started: 8 July 2021

(c) Author(s) 2021. CC BY 4.0 License.

\begin{tabular}{|c|c|c|c|c|c|c|c|c|c|}
\hline $\begin{array}{l}\text { Upper } \\
\text { Depth } \\
\text { (cm) }\end{array}$ & $\begin{array}{c}\text { Sediment } \\
\text { Type }\end{array}$ & $\begin{array}{c}\text { Supported } \\
{ }^{210} \mathrm{~Pb}\left({ }^{226} \mathrm{Ra}\right. \\
\mathrm{Bq} / \mathrm{kg})\end{array}$ & $\begin{array}{c}{ }^{210} \mathrm{~Pb} \text { total } \\
(\mathrm{Bq} / \mathrm{kg})\end{array}$ & $\begin{array}{l}+/-1 \mathrm{SD} \\
(\mathrm{Bq} / \mathbf{k g})\end{array}$ & $\begin{array}{l}{ }^{210} \mathrm{~Pb}_{\text {exs }} \\
(\mathrm{Bq} / \mathrm{kq})\end{array}$ & $\begin{array}{l}+/-1 \mathrm{SD} \\
(\mathrm{Bq} / \mathbf{k g})\end{array}$ & Slope $\left(\mathrm{cm}^{2} / \mathrm{g}\right)$ & $\begin{array}{c}\text { Age }(y r \\
\text { before } \\
\text { 2016) }\end{array}$ & $\begin{array}{c}\text { Age SD } \\
(y \mathbf{r})\end{array}$ \\
\hline 5 & humus + peat & 2.63 & 175.1 & 6.8 & 172.5 & 6.8 & & 1.48 & 0.07 \\
\hline 7 & humus + peat & 2.63 & 169.7 & 6.7 & 167.1 & 6.7 & & 1.99 & 0.09 \\
\hline 9 & peat & 2.63 & 157.6 & 6.5 & 155.0 & 6.5 & & 3.00 & 0.14 \\
\hline 12 & peat & 2.63 & 145.0 & 6.2 & 142.4 & 6.2 & & 5.03 & 0.24 \\
\hline 16 & peat + sand & 2.63 & 131.8 & 5.9 & 129.2 & 5.9 & & 8.11 & 0.39 \\
\hline 19 & peat + sand & 2.63 & 117.8 & 5.2 & 115.2 & 5.2 & & 11.90 & 0.57 \\
\hline $20 * *$ & peat + sand & & & & & & & 13.26 & 0.63 \\
\hline 22 & sand & 2.63 & 101.4 & 4.9 & 98.7 & 4.9 & & 16.08 & 0.76 \\
\hline 27 & sand & 2.63 & 89.3 & 4.5 & 86.6 & 4.5 & & 23.50 & 1.12 \\
\hline $33 *$ & sand+clay & 2.63 & 75.9 & 3.9 & 73.3 & 3.9 & & 31.26 & 1.49 \\
\hline 37 & clay & 2.63 & 57.4 & 0.5 & 54.8 & 0.5 & & 36.58 & 1.74 \\
\hline \multicolumn{10}{|c|}{ GBK 1-4 (LM) ${ }^{c}$} \\
\hline 0 & peat & 2.63 & 244.9 & 5.9 & 242.3 & 5.9 & $0.76 \pm 0.16$ & 6.13 & 1.29 \\
\hline 2 & peat & 2.63 & 221.8 & 6.0 & 219.1 & 6.0 & & 19.37 & 4.08 \\
\hline $4 *$ & peat & 2.63 & 175.5 & 6.1 & 172.9 & 6.1 & & 32.11 & 6.76 \\
\hline 8 & peat & 2.63 & 49.3 & 2.4 & 46.6 & 2.4 & & 61.29 & 12.90 \\
\hline 10 & peat-sand & 2.63 & 7.0 & 0.8 & 4.3 & 0.8 & & 77.71 & 16.36 \\
\hline $11 * *$ & peat + sand & & & & & & & 87.76 & 18.47 \\
\hline 12 & Sand & 2.63 & 8.4 & 0.8 & 5.8 & 0.9 & & & \\
\hline 14 & Sand & 2.63 & 6.8 & 0.7 & 4.2 & 0.7 & & & \\
\hline 16 & Sand & 2.63 & 6.5 & 0.7 & 3.8 & 0.7 & & & \\
\hline 18 & Sand & 2.63 & 5.4 & 0.7 & 2.8 & 0.7 & & & \\
\hline 20 & Sand & 2.63 & 7.4 & 0.8 & 4.8 & 0.8 & & & \\
\hline 22 & Sand & 2.63 & 116.0 & 4.3 & 113.4 & 4.3 & & & \\
\hline 23 & Sand & 2.63 & 7.9 & 1.0 & 5.3 & 1.0 & & & \\
\hline $\begin{array}{c}3\left({ }^{226} \mathrm{Ra}\right) \\
20\end{array}$ & & 2.58 & & 0.38 & & & & & \\
\hline$\left({ }^{226} \mathrm{Ra}\right)$ & & 2.68 & & 0.38 & & & & & \\
\hline
\end{tabular}

\section{TMF 1-2 (LM) ${ }^{\text {b }}$}

$\begin{array}{rccccccrrr}1 & \text { humus+peat } & 4.33 & 269.3 & 6.9 & 264.9 & 6.9 & 0.54 \pm 0.061 & 6.91 & 0.79 \\ 3 & \text { peat }+ \text { mud } & 4.33 & 173.9 & 6.4 & 169.5 & 6.4 & & 14.51 & 1.65 \\ 5 & \text { peat }+ \text { mud } & 4.33 & 184.0 & 5.9 & 179.7 & 5.9 & & 23.66 & 2.69\end{array}$


https://doi.org/10.5194/bg-2021-157

Preprint. Discussion started: 8 July 2021

(c) Author(s) 2021. CC BY 4.0 License.

\begin{tabular}{|c|c|c|c|c|c|c|c|c|c|}
\hline $\begin{array}{l}\text { Upper } \\
\text { Depth } \\
\text { (cm) }\end{array}$ & $\begin{array}{c}\text { Sediment } \\
\text { Type }\end{array}$ & $\begin{array}{c}\text { Supported } \\
{ }^{210} \mathrm{~Pb}\left({ }^{226} \mathrm{Ra},\right. \\
\mathrm{Bq} / \mathrm{kg})\end{array}$ & $\begin{array}{c}{ }^{210} \mathrm{~Pb} \text { total } \\
(\mathrm{Bq} / \mathrm{kg})\end{array}$ & $\begin{array}{l}+/-1 \text { SD } \\
(\mathrm{Bq} / \mathbf{k g})\end{array}$ & $\begin{array}{l}{ }^{210} \mathrm{~Pb}_{\text {exs }} \\
(\mathrm{Bq} / \mathrm{kq})\end{array}$ & $\begin{array}{l}+/-1 \text { SD } \\
(\mathbf{B q} / \mathbf{k g})\end{array}$ & Slope $\left(\mathrm{cm}^{2} / \mathrm{g}\right)$ & $\begin{array}{c}\text { Age (yr } \\
\text { before } \\
2016)\end{array}$ & $\begin{array}{c}\text { Age SD } \\
(\mathrm{yr})\end{array}$ \\
\hline $7 *$ & peat + mud & & & & & & & 33.0 & 3.76 \\
\hline 8 & peat + mud & 4.33 & 86.6 & 4.3 & 82.2 & 4.3 & & 36.78 & 4.19 \\
\hline 11 & peat + mud & 4.33 & 65.9 & 3.9 & 61.6 & 3.9 & & 49.22 & 5.61 \\
\hline 14 & peat + mud & 4.33 & 54.0 & 3.2 & 49.7 & 3.3 & & 61.82 & 7.04 \\
\hline $15^{* *}$ & peat + mud & & & & & & & 66.7 & 7.59 \\
\hline 18 & sand & 4.33 & 7.1 & 1.5 & 2.8 & 1.5 & & & \\
\hline $\begin{array}{c}18 \\
(226 \mathrm{Ra}) \\
\end{array}$ & & 4.33 & & 0.33 & & & & & \\
\hline
\end{tabular}

\section{TMF 2-1 (HM) ${ }^{b}$}

\begin{tabular}{|c|c|c|c|c|c|c|c|c|c|}
\hline 0 & humus & 3.50 & 194.4 & 7.2 & 190.9 & 7.2 & $\begin{array}{l}0.063 \pm \\
0.0027\end{array}$ & 0.34 & 0.01 \\
\hline 4 & peat + mud & 3.50 & 184.9 & 7.0 & 181.4 & 7.0 & & 2.92 & 0.13 \\
\hline 5 & peat + mud & 3.50 & 177.8 & 6.9 & 174.3 & 6.9 & & 4.19 & 0.18 \\
\hline 6 & peat + mud & 3.50 & 173.1 & 6.8 & 169.6 & 6.8 & & 5.40 & 0.24 \\
\hline 7 & peat + mud & 3.50 & 159.9 & 6.5 & 156.4 & 6.5 & & 7.04 & 0.31 \\
\hline 8 & peat + mud & 3.50 & 148.2 & 6.3 & 144.7 & 6.3 & & 8.71 & 0.38 \\
\hline 10 & peat + mud & 3.50 & 133.5 & 6.0 & 130.0 & 6.0 & & 11.29 & 0.49 \\
\hline 11 & sand+peat & 3.50 & 120.9 & 5.4 & 117.4 & 5.4 & & 12.76 & 0.56 \\
\hline 13 & sand+peat & 3.50 & 109.3 & 5.1 & 105.8 & 5.1 & & 15.65 & 0.68 \\
\hline 16 & sand+peat & 3.50 & 98.1 & 4.6 & 94.6 & 4.7 & & 20.97 & 0.92 \\
\hline $21 *$ & sand+peat & 3.50 & 80.3 & 4.3 & 76.8 & 4.3 & & 31.84 & 1.39 \\
\hline 24 & sand+peat & 3.50 & 67.9 & 3.8 & 64.4 & 3.8 & & 37.69 & 1.65 \\
\hline $25 * *$ & sand+peat & & & & & & & 38.5 & 1.68 \\
\hline 27 & sand+gravel & 3.50 & 52.7 & 0.5 & 49.2 & 0.6 & & & \\
\hline $5\left({ }^{226} \mathrm{Ra}\right)$ & & 3.50 & & 0.33 & & & & & \\
\hline
\end{tabular}

${ }^{a}$ measurements from Core Scientific International

${ }^{\mathbf{b}}$ measurements from Flett Research Ltd

c measurements from My Core Scientific Laboratory

$550 *$ Depth of 30-yr horizon

** Depth basal age (age determined in deepest sediment layer containing peat overlying sand, clay, or gravel)

Note that the 30-yr horizon can occur below the depth of the basal age. 
https://doi.org/10.5194/bg-2021-157

Preprint. Discussion started: 8 July 2021

(c) Author(s) 2021. CC BY 4.0 License.

Figure A1. Core stratigraphies. Dated high marsh cores (asterisks) were CBE1-1, CRF2-1, GBK1-2, and TMF2-1; Dated low marsh cores were CBE1-5, CRF3-2, GBK1-4, and TMF1-2. Corrected depth (cm) reflects correction for core compaction.

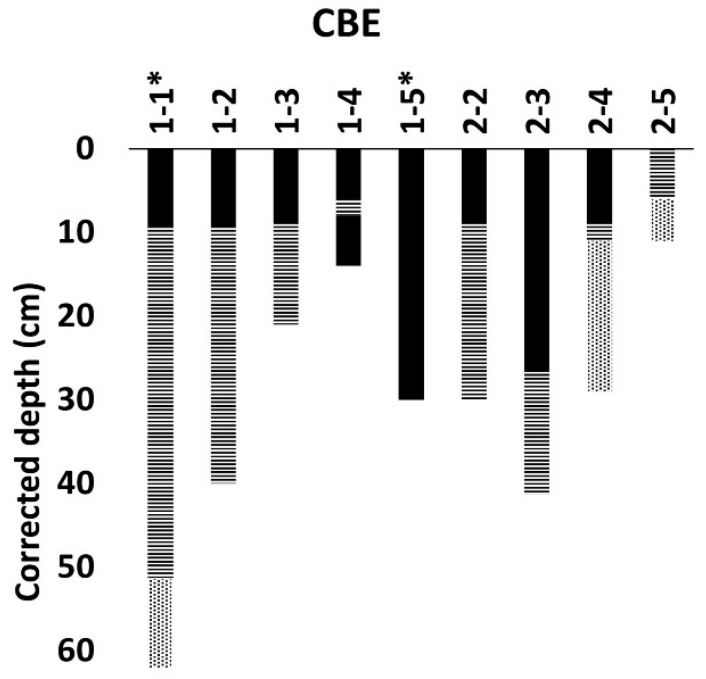

70

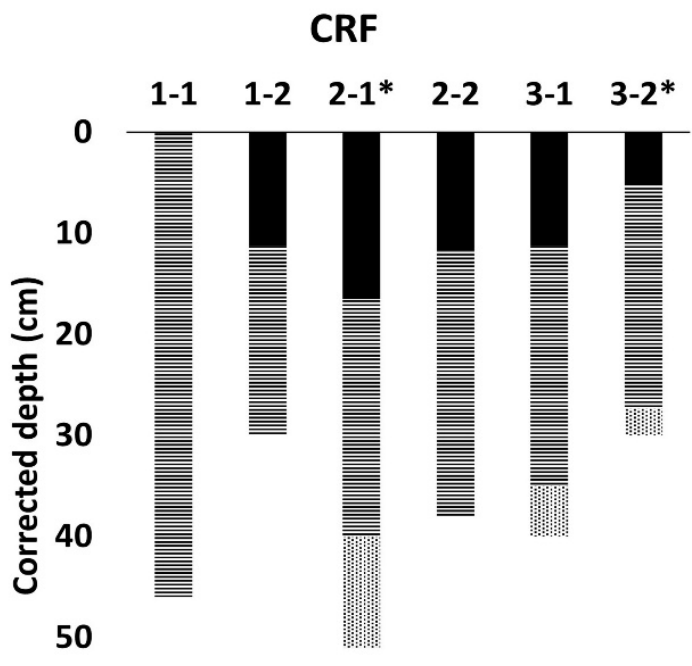

60

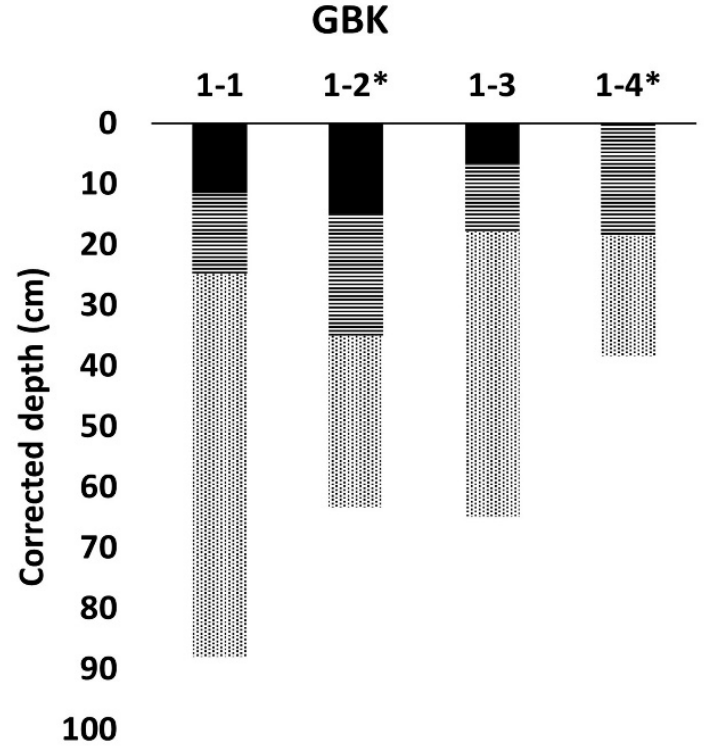

TMF

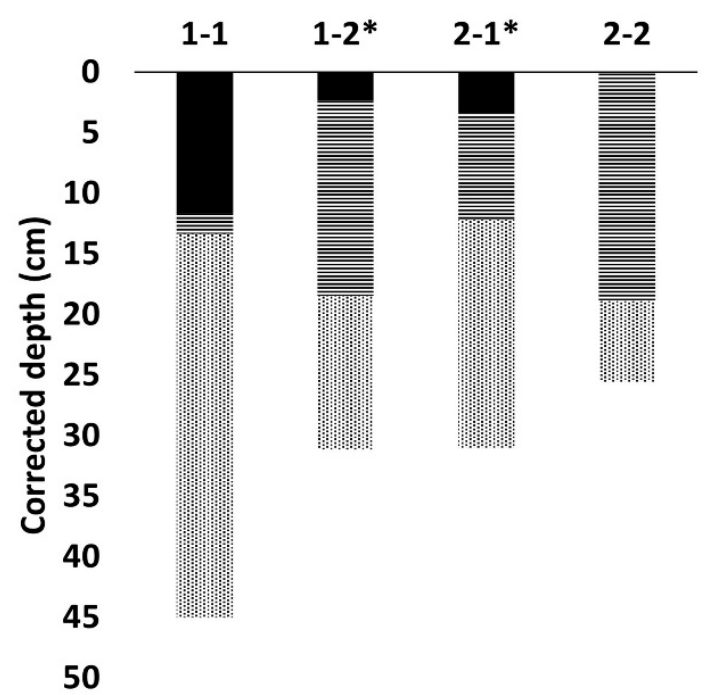


https://doi.org/10.5194/bg-2021-157

Preprint. Discussion started: 8 July 2021

(c) Author(s) 2021. CC BY 4.0 License.

Figure A2. \%LOI-to-\%C Relationship. Relationship between measured LOI values and calculated \%C, using elemental analyser EA data on set of 93 subsamples. Measurements from core CBE 1-5 were not used for calculating this relationship due to suspected measurement error.

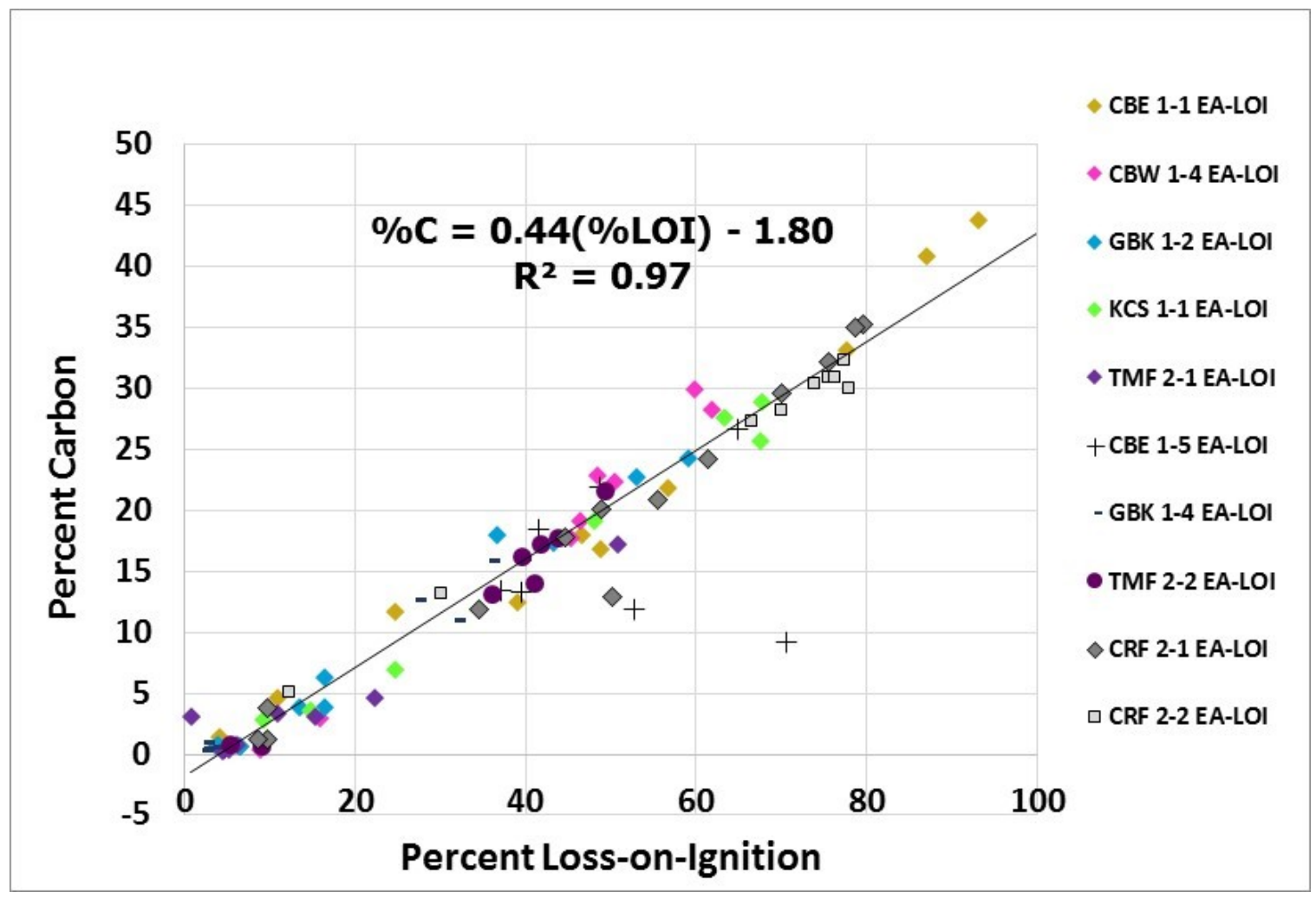


https://doi.org/10.5194/bg-2021-157

Preprint. Discussion started: 8 July 2021

(c) Author(s) 2021. CC BY 4.0 License.

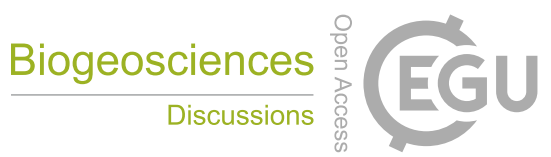

Figure A3. ${ }^{210} \mathrm{~Pb}$ inventory $\left(\mathrm{Bq} \mathrm{m}^{-2}\right)$ in high and low marsh cores.

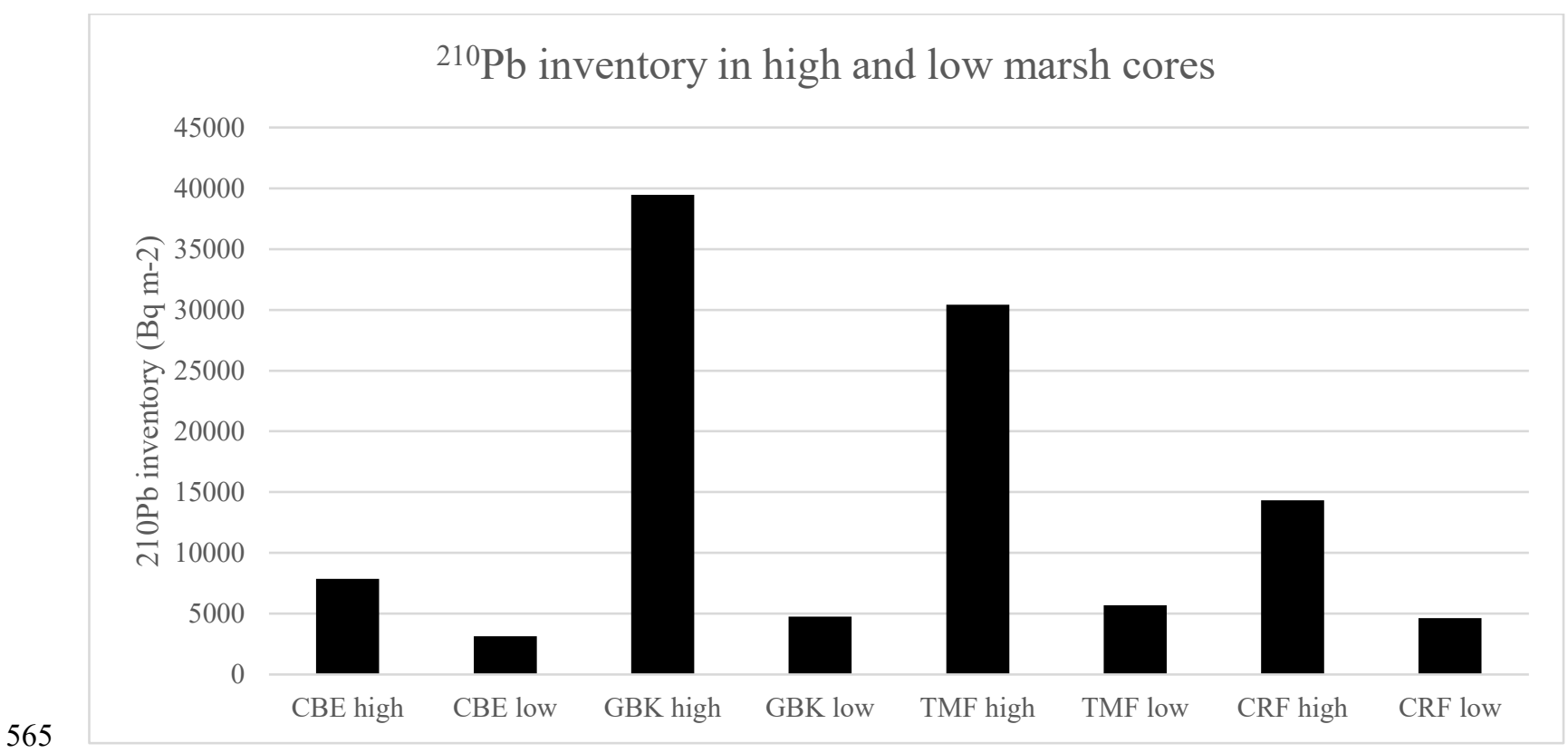


https://doi.org/10.5194/bg-2021-157

Preprint. Discussion started: 8 July 2021

(c) Author(s) 2021. CC BY 4.0 License.

(c) (i)

\section{Appendix B Groundtruthing Marsh Zone Designations: Detrended Correspondence Analysis}

We used colour orthophotos to visually determine the areas of marsh zones using ArcMap 10.5.1 area measurement tools. A vegetation survey also determined the marsh zone of each core sample site, and vegetation data were examined using a detrended correspondence analysis to verify that vegetation assemblages reflected distinct low and high marsh zones identified from the orthophotos (Hill and Gauch 1980).

Our comparison showed that differentiating high and low marsh using orthophotos matched with field vegetation data for 32 of 34 (94\%) of cores. Both CRF 1-2 and CRF 2-2 were classified as low marsh by vegetation survey but fell within the high marsh using the visual orthophotography method. These cores lie $16 \mathrm{~m}$ (CRF 1-2) and $12 \mathrm{~m}$ (CRF 2-2) away from the low marsh boundary as measured using orthophotos, which is less than their distances from the nearest high marsh cores $(17 \mathrm{~m}$ and $23 \mathrm{~m}$, respectively). All other cores fell within the correct marsh zone.

We also conducted a detrended correspondence analysis (Hill and Gauch 1980) of vegetation data to determine that vegetation encountered in the vicinity of the core samples reflected distinct marsh zones using Canoco v4.5 software. We classified of marsh zones by presence/absence and percent cover of low marsh or high marsh vegetation (e.g. Deur 2000).

580 The analysis showed accurate fit of low marsh cores with low marsh vegetation and high marsh cores with high marsh vegetation, plus the addition of a somewhat indistinct, third cluster of vegetation possibly representing the backshore. This square root-transformed model accounted for $33.2 \%$ of all variance in the vegetation dataset (sum of eigenvalues $=3.29$ ). Cores with low marsh vegetation clustered together while high marsh cores clustered separately. An additional, slightly distinct third cluster of backshore vegetation indicates that some high marsh cores may have been extracted from close to the boundary with a freshwater-dominated backshore or salt-tolerant meadow. The distinction between a salt marsh and a bordering freshwater area has complicated efforts to classify marshes by salinity (Duarte et al. 2013), but this result shows that clustering of vegetation type corresponds reasonably well with each site's designation as high or low marsh. 
https://doi.org/10.5194/bg-2021-157

Preprint. Discussion started: 8 July 2021

(c) Author(s) 2021. CC BY 4.0 License.

Figure B1 Detrended correspondence analysis results for Marsh vegetation data. Low marsh cores (top, purple squares) corresponded reasonably well with vegetation identified as low marsh, and high marsh cores corresponded with a distinct cluster of high marsh vegetation. The far bottom-right may indicate a population of less salt-tolerant, backshore vegetation but it is indistinct from the high marsh.
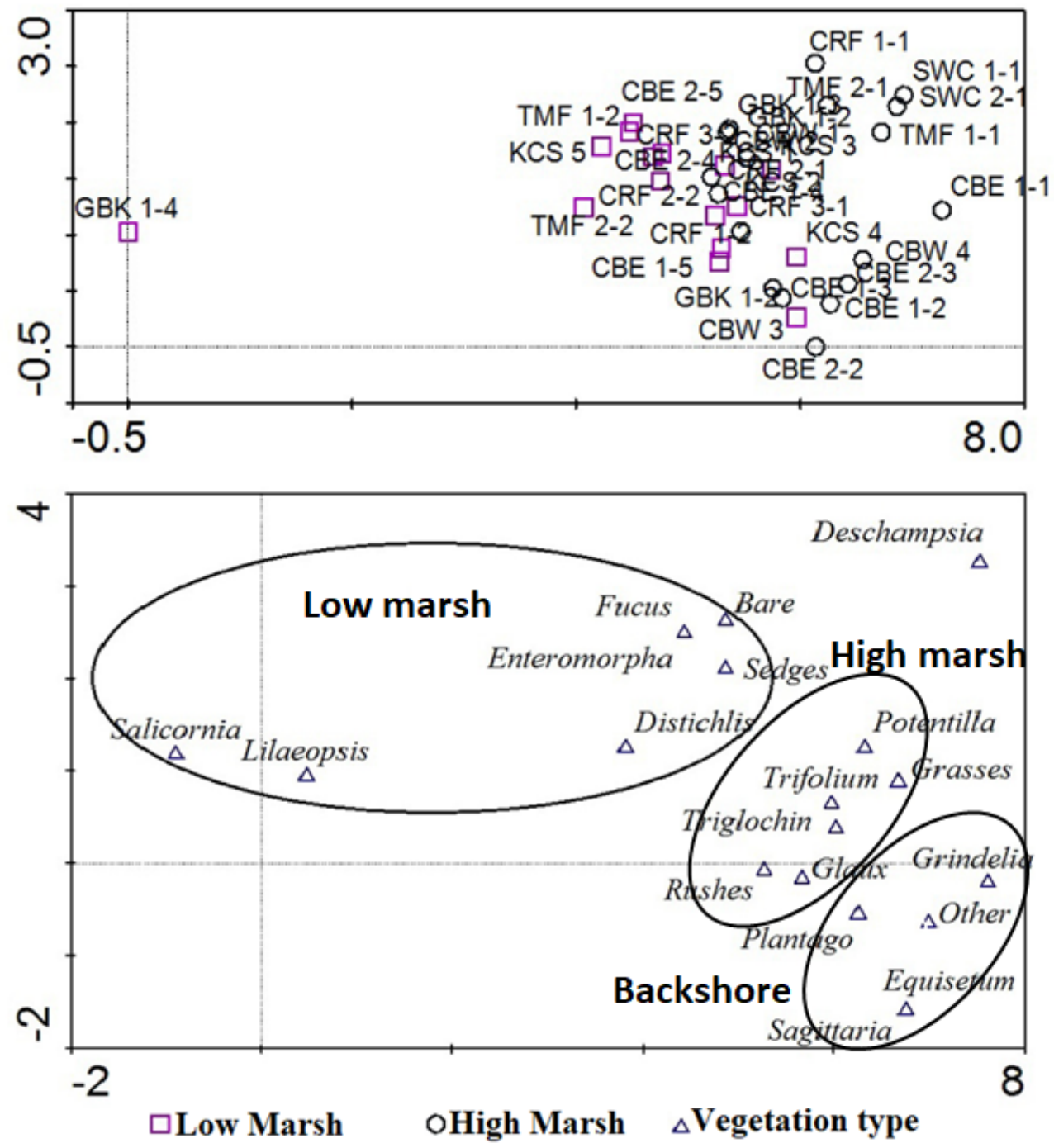
https://doi.org/10.5194/bg-2021-157

Preprint. Discussion started: 8 July 2021

(c) Author(s) 2021. CC BY 4.0 License.

595 Figure B2 Reference used for determining marsh stratum based on vegetation. Source: Deur 2000.

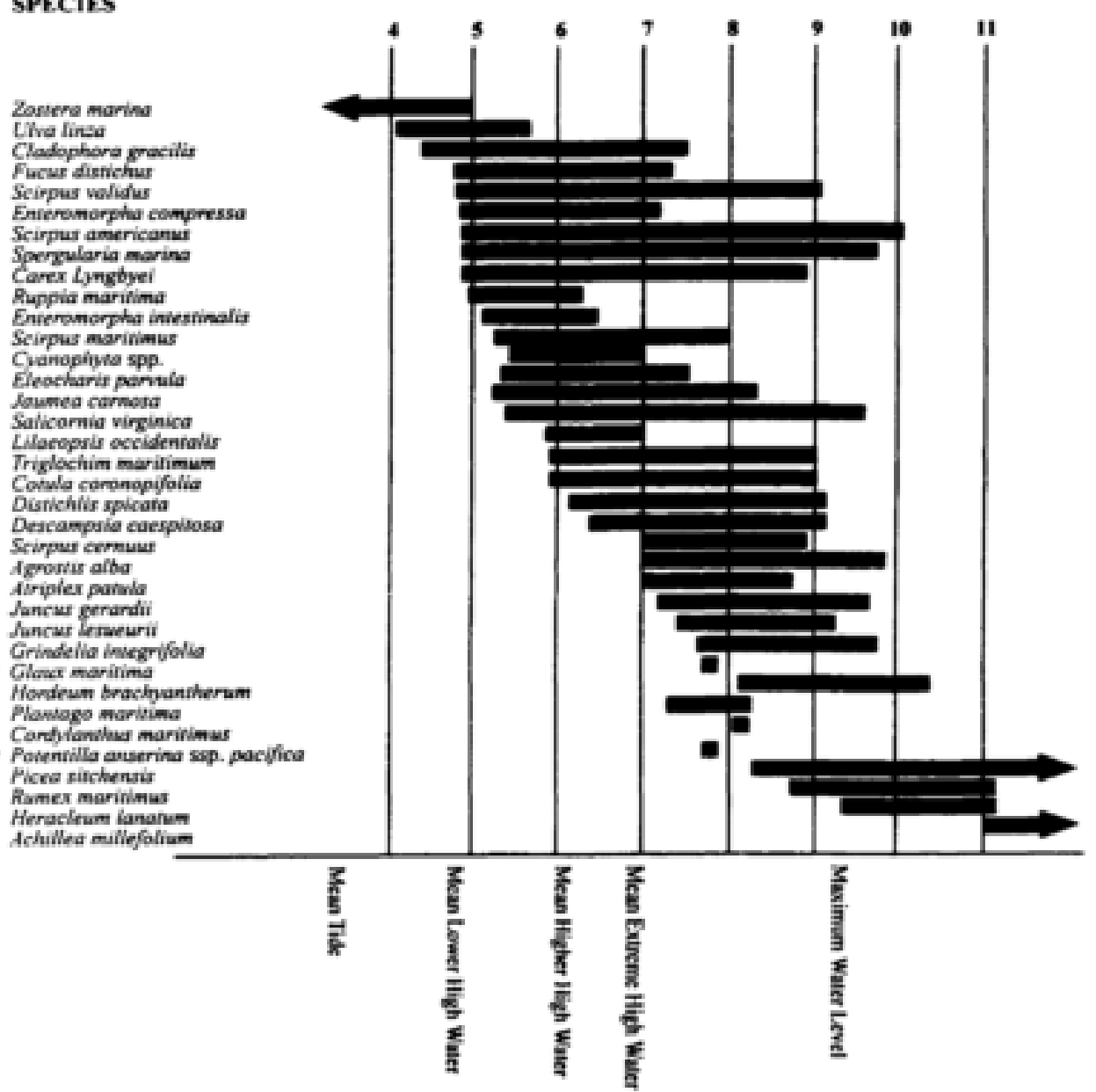

Adapted from Jefferson (1974) 
https://doi.org/10.5194/bg-2021-157

Preprint. Discussion started: 8 July 2021

(c) Author(s) 2021. CC BY 4.0 License.

(c) (i)

\section{Data Availability}

600 Data produced as part of this project are currently being submitted to the Pangaea database with the following doi: https://doi.pangaea.de/10.1594/PANGAEA.889454

\section{Author contribution}

MGP and KEK acquired funding for the project. SC, MGP, and KEK designed the experiments and SC and MGP carried them out. SC conducted laboratory measurements and SC, CO, MG, MGP and KEK contributed to data analysis. KEK, SC, and $\mathrm{CO}$ were responsible for data curation. SC and KEK prepared the manuscript with contributions from all co-authors.

\section{Competing interests}

The authors declare that they have no conflict of interest.

\section{Acknowledgements}

The authors extend their gratitude to the following individuals for their contributions to this research, alphabetically: Dr.

610 Richard Atleo, Celeste Barlow, Hasini Basnayake, Dr. Douglas Deur, Dan Harrison, Hannah Jensen, Victoria Lamothe, Dr. Dana Lepofsky, Gemma MacFarland, Aimee McGowan, Bryn Montgomery, Yiga Phuntsok, Ellie Simpson, Maureen Soon, and Dr. Nancy Turner. We thank Parks Canada for in-kind support at both Pacific Rim National Park Reserve and the Vancouver office, the Raincoast Education Society for their expertise in the field and access to their grounds to reach our study sites, and the Ahousaht First Nation for allowing us to collect samples from their territory.

\section{References}

Abbott, K. M., Elsey-Quirk, T., and DeLaune, R. D.: Factors influencing blue carbon accumulation across a 32-year chronosequence of created coastal marshes, Ecosphere, 10, 10.1002/ecs2.2828, 2019.

Adams, C. A., Andrews, J. E., and Jickells, T.: Nitrous oxide and methane fluxes vs. carbon, nitrogen and phosphorous burial in new intertidal and saltmarsh sediments, Science of The Total Environment, 434, 240-251, https://doi.org/10.1016/j.scitotenv.2011.11.058, 2012.

Arias-Ortiz, A., Masqué, P., Garcia-Orellana, J., Serrano, O., Mazarrasa, I., Marbà, N., Lovelock, C. E., Lavery, P. S., and Duarte, C. M.: Reviews and syntheses: $210 \mathrm{~Pb}$-derived sediment and carbon accumulation rates in vegetated coastal ecosystems - setting the record straight, Biogeosciences, 15, 6791-6818, 10.5194/bg-15-6791-2018, 2018. 
https://doi.org/10.5194/bg-2021-157

Preprint. Discussion started: 8 July 2021

(c) Author(s) 2021. CC BY 4.0 License.

Bridgham, S. D., Megonigal, J. P., Keller, J. K., Bliss, N. B., and Trettin, C.: The carbon balance of North American wetlands, Wetlands, 26, 889-916, 10.1672/0277-5212(2006)26[889:TCBONA]2.0.CO;2, 2006.

Callaway, J.C., Borgnis, E.L., Turner, R.E., and Milan, C.S.: Carbon sequestration and sediment accretion in San Francisco Bay tidal wetlands, Estuarine, Coastal and Shelf Science, 35, 1163-1181, 2012.

Chmura, G. L., Anisfeld, S. C., Cahoon, D. R., and Lynch, J. C.: Global carbon sequestration in tidal, saline wetland soils, Global Biogeochem. Cycles, 17, doi:10.1029/2002GB001917, 2003.

Chmura, G. L., Kellman, L., and Guntenspergen, G. R.: The greenhouse gas flux and potential global warming feedbacks of a northern macrotidal and microtidal salt marsh, Environmental Research Letters, 6, 044016, 10.1088/17489326/6/4/044016, 2011.

Connor, R. F., Chmura, G. L., and Beecher, C. B.: Carbon accumulation in bay of fundy salt marshes: Implications for restoration of reclaimed marshes, Global Biogeochemical Cycles, 15, 943-954, https://doi.org/10.1029/2000GB001346, 2001.

Corbett, D. R. and Walsh, J. P.: ${ }^{210}$ Lead and ${ }^{137}$ Cesium: establishing a chronology for the last century. In: Handbook of SeaLevel Research, Shennan, I., Long, A. J., and Horton, B. P. (Eds.), John Wiley \& Sons, Ltd., Chichester, UK, 2015.

Craft, C., Megonigal, P., Broome, S., Stevenson, J., Freese, R., Cornell, J., Zheng, L., and Sacco, J.: The pace of ecosystem development of constructed Spartina alterniflora marshes, Ecological Applications, 13, 1417-1432, https://doi.org/10.1890/02-5086, 2003.

Crooks, S., Rybczyk, J., O’Connell, K., Devier, D.L., Poppe, K., and Emmett-Mattox, S.: Coastal Blue Carbon Opportunity Assessment for the Snohomish Estuary: The Climate Benefits of Estuary Restoration, Report by Environmental Science Associates, Bellingham, WA, USA, pp. 19-43, 2014.

Davis, R. B., Hess, C. T., Norton, S. A., Hanson, D. W., Hoagland, K. D., and Anderson, D. S.: ${ }^{137} \mathrm{Cs}$ and ${ }^{210} \mathrm{~Pb}$ dating of sediments from soft-water lakes in New England (U.S.A.) and Scandinavia, a failure of 137Cs dating, Chemical Geology, 44, 151-185, https://doi.org/10.1016/0009-2541(84)90071-8, 1984.

Deur, D.: A Domesticated Landscape: Native American plant cultivation on the Northwest coast of North America, PhD dissertation, Louisiana State University, Baton Rouge, LA, USA, pp. 69-251, 2000.

Donato, D. C., Kauffman, J. B., Murdiyarso, D., Kurnianto, S., Stidham, M., and Kanninen, M.: Mangroves among the most carbon-rich forests in the tropics, Nature Geoscience, 4, 293-297, 10.1038/ngeo1123, 2011.

Drexler, J. Z., Woo, I., Fuller, C. C., and Nakai, G.: Carbon accumulation and vertical accretion in a restored versus historic salt marsh in southern Puget Sound, Washington, United States, Restoration Ecology, 27, 1117-1127, https://doi.org/10.1111/rec.12941, 2019.

Duarte, C. M., Middelburg, J. J., and Caraco, N.: Major role of marine vegetation on the oceanic carbon cycle, Biogeosciences, 2, 1-8, 10.5194/bg-2-1-2005, 2005.

Duarte, C. M., Losada, I. J., Hendriks, I. E., Mazarrasa, I., and Marbà, N.: The role of coastal plant communities for climate change mitigation and adaptation, Nature Climate Change, 3, 961-968, 10.1038/nclimate1970, 2013. 
https://doi.org/10.5194/bg-2021-157

Preprint. Discussion started: 8 July 2021

(c) Author(s) 2021. CC BY 4.0 License.

(c) (i)

2016.

Canadian Climate Normals 1981-2010

Station

Data:

Tofino

A.http://climate.weather.gc.ca/climate_normals/results_1981_2010_e.html?searchType=stnName\&txtStationName

660

$=$ Tofino\&searchMethod $=$ contains \& txtCentralLatMin $=0 \&$ txtCentralLatSec $=0 \&$ txtCentralLongMin $=0 \&$ txtCentralLo ngSec $=0 \& \operatorname{stnID}=277 \&$ dispBack=1. Last access: 13 November, 2016.

Fisheries and Oceans Canada TOFINO - Tides, Currents, and Water Levels. http://www.tides.gc.ca/eng/data/table/2016/wlev_ref/8615. Last Access: 13 June, 2017, 2016.

Froelich, P. N.: Analysis of organic carbon in marine sediments, Limnology and Oceanography, 25, 564-572, https://doi.org/10.4319/lo.1980.25.3.0564, 1980.

Gailis, M., Kohfeld, K. E., Pellatt, M. G., and Carlson, D.: Quantifying blue carbon for the largest salt marsh in southern British Columbia: implications for regional coastal management, Coastal Engineering Journal, https://doi.org/10.1080/21664250.2021.1894815, in press 2021.

Havens, K., Varnell, L., and Watts, B.: Maturation of a constructed tidal marsh relative to two natural reference tidal marshes over 12 years, Ecological Engineering, 18, 305-315, 2002.

Heiri, O., Lotter, A. F., and Lemcke, G.: Loss on ignition as a method for estimating organic and carbonate content in sediments: reproducibility and comparability of results, Journal of Paleolimnology, 25, 101-110, 10.1023/A:1008119611481, 2001.

Hedges, J.I. and Stern, J.H.: Carbon and nitrogen determinations of carbonate-containing solids, Limnology and Oceanography 29(3), 657-663, 1984.

Hill, M. O. and Gauch, H. G.: Detrended correspondence analysis: An improved ordination technique, Vegetatio, 42, 47-58, 10.1007/BF00048870, 1980.

Hodgson, C. and Spooner, A.: The K'omoks and Squamish Estuaries: A Blue Carbon Pilot Project, Final Report to the North American Partnership for Environmental Community Action (NAPECA), (Grant 2014-1362), Comox Valley Watershed Society, Comox, BC, Canada, 2016.

Howard, J., Hoyt, S., Isensee, K., Pidgeon, E., and Telszewski, M.: (eds.) Coastal Blue Carbon: Methods for assessing carbon stocks and emissions factors in mangroves, tidal salt marshes, and seagrass meadows, Conservation International, Intergovernmental Oceanographic Commission of UNESCO, International Union for Conservation of Nature, Arlington, Virginia, USA, 15-24; 149-150, 2014.

Howard, J., Sutton-Grier, A., Herr, D., Kleypas, J., Landis, E., McLeod, E., Pidgeon, E., and Simpson, S.: Clarifying the role of coastal and marine systems in climate mitigation, Frontiers in Ecology and the Environment, 15(1): 42-50, doi:10.1002/fee.1451, 2017.

Howe, A. J., Rodríguez, J. F., and Saco, P. M.: Surface evolution and carbon sequestration in disturbed and undisturbed wetland soils of the Hunter estuary, southeast Australia, Estuarine, Coastal and Shelf Science, 84, 75-83, https://doi.org/10.1016/j.ecss.2009.06.006, 2009. 
https://doi.org/10.5194/bg-2021-157

Preprint. Discussion started: 8 July 2021

(c) Author(s) 2021. CC BY 4.0 License.

IPCC, Hiraishi, $\quad$ T., $\quad$ Krug, $\quad$ T., Tanabe, $\quad$ K., Srivastava, N., Baasansuren, J., Fukuda, $\quad$ M., and Troxler, T.G. (Eds.): Supplement to the 2006 IPCC Guidelines for National Greenhouse Gas Inventories: Wetlands, Intergovernmental Panel on Climate Change, Switzerland, 2014.

Jefferson, C.: Some Aspects of Plant Succession in Oregon Estuarine Salt Marshes, (unpublished Ph.D. dissertation, Oregon State University, Corvallis, OR, USA, 1973.

Johannessen, S. C. and Macdonald, R. W.: Geoengineering with seagrasses: is credit due where credit is given?, Environmental Research Letters, 11, 113001, 10.1088/1748-9326/11/11/113001, 2016.

Kauffman, J. B., Giovanonni, L., Kelly, J., Dunstan, N., Borde, A., Diefenderfer, H., Cornu, C., Janousek, C., Apple, J., and Brophy, L.: Total ecosystem carbon stocks at the marine-terrestrial interface: Blue carbon of the Pacific Northwest Coast, United States, Global Change Biology, 26, 5679-5692, https://doi.org/10.1111/gcb.15248, 2020.

Kelleway, J. J., Saintilan, N., Macreadie, P. I., Baldock, J. A., and Ralph, P. J.: Sediment and carbon deposition vary among vegetation assemblages in a coastal salt marsh, Biogeosciences, 14, 3763-3779, 10.5194/bg-14-3763-2017, 2017.

Kirwan, M. L., Walters, D. C., Reay, W. G., and Carr, J. A.: Sea level driven marsh expansion in a coupled model of marsh erosion and migration, Geophysical Research Letters, 43, 4366-4373, https://doi.org/10.1002/2016GL068507, 2016.

Krishnaswamy, S., Lal, D., Martin, J. M., and Meybeck, M.: Geochronology of lake sediments, Earth and Planetary Science Letters, 11, 407-414, https://doi.org/10.1016/0012-821X(71)90202-0, 1971.

Kurz, W.A., Shaw, C.H., Boisvenue, C., Stinson, G., Metsaranta, J., Leckie, D., Dyk, A., Smyth, C. and Neilson, E.T: Carbon in Canada's boreal forest—a synthesis Environmental Reviews, 21, 260-292, 10.1139/er-2013-0041, 2013.

Mathieu, G. G., Biscaye, P. E., Lupton, R. A., and Hammond, D. E.: System for measurement of 222Rn at low levels in natural waters, Health Phys, 55, 989-992, 1988.

Mazzotti, S., Jones, C., and Thomson, R.E.: Relative and absolute sea level rise in western Canada and northwestern United States from a combined tide gauge-GPS analysis, Journal of Geophysical Research, 113:1-19, C11019, doi:10.1029/2008JC004835, 2008.

Mazzotti, S, Lambert, A., Courtier, N. Nykolaishen, L., and Dragert, H.: Crustal uplift and sea level rise in northern Cascadia from GPS, absolute gravity, and tide gauge data, Geophysical Research Letters, 34, L15306. https://doi.org/10.1029/2007GL030283, 2007.

McLeod, E., Chmura, G.L., Bouillon, S., Salm, R., Björk, M., Duarte, C.M., Lovelock, C.E., Schlesinger, W.H., and Silliman, B.R.: A blueprint for blue carbon: toward an improved understanding of the role of vegetated coastal habitats in sequestering $\mathrm{CO}_{2}$, Frontiers in Ecology and the Environment, 9(10):552-560, 2011.

720 Mcowen, C.J., Weatherdon L., Van Bochove, J.W., Sullivan, E., Blyth, S., Zockler, C., Stanwell-Smith, D., Kingston, N., Martin C.S., Spalding M., and Fletcher, S.: A global map of saltmarshes, Biodiversity Data Journal 5: e11764, doi: 10.3897/BDJ.5.e11764, 2017. 
https://doi.org/10.5194/bg-2021-157

Preprint. Discussion started: 8 July 2021

(c) Author(s) 2021. CC BY 4.0 License.

(c) (i)

Montillet, J.-P., Melbourne, T. I., and Szeliga, W. M.: GPS Vertical Land Motion Corrections to Sea-Level Rise Estimates in the Pacific Northwest, Journal of Geophysical Research: Oceans, 123, 1196-1212, https://doi.org/10.1002/2017JC013257, 2018.

Nuwer, J. M. and Keil, R. G.: Sedimentary organic matter geochemistry of Clayoquot Sound, Vancouver Island, British Columbia, Limnology and Oceanography, 50, 1119-1128, https://doi.org/10.4319/lo.2005.50.4.1119, 2005.

Olid, C., Garcia-Orellana, J., Martínez-Cortizas, A., Masqué, P., Peiteado-Varela, E., and Sanchez-Cabeza, J.-A.: Multiple site study of recent atmospheric metal $(\mathrm{Pb}, \mathrm{Zn}$ and $\mathrm{Cu})$ deposition in the NW Iberian Peninsula using peat cores, Sci Total Environ, 408, 5540-5549, 10.1016/j.scitotenv.2010.07.058, 2010.

Ouyang, X., and Lee, S.Y.: Updated estimates of carbon accumulation rates in coastal marsh sediments, Biogeosciences, 11(18): 5057-5071, http://doi.org/10.5194/bg-11-5057-2014, 2014.

Pendleton, L., Donato, D., Murray, B., Crooks, S., Jenkins, W., Sifleet, S., Craft, C., Fourqurean, J. W., Kauffman, J. B., Marba', N. r., Megonigal, P., Pidgeon, E., Herr, D., Gordon, D., and Baldera, A.: Estimating global blue carbon emissions from conversion and degradation of vegetated coastal ecosystems, PLoS One, 7, e43542, doi:10.1371/journal.pone.0043542, 2012.

Poffenbarger, H. J., Needelman, B. A., and Megonigal, J. P.: Salinity Influence on Methane Emissions from Tidal Marshes, Wetlands, 31, 831-842, 10.1007/s13157-011-0197-0, 2011.

Poppe, K.L., and J.M. Rybczyk. 2019. A blue carbon assessment for the Stillaguamish River estuary: Quantifying the climate benefits of tidal marsh restoration. In Summary report prepared by Western Washington University for Washington Sea Grant and The Nature Conservancy, 19. Bellingham, WA, USA: Western Washington University.

Porter, G.L.: Vegetation-environment relationships in the tidal marshes of the Fraser River Delta, British Columbia. Masters, The University of British Columbia Vancouver, BC, Canada, 1982.

Postlethwaite, V. R., McGowan, A. E., Kohfeld, K. E., Robinson, C. L. K., and Pellatt, M. G.: Low blue carbon storage in eelgrass (Zostera marina) meadows on the Pacific Coast of Canada, PLoS One, 13, e0198348, 10.1371/journal.pone.0198348, 2018.

Ryder, J.L., Kenyon, J.K., Buffett, D., Moore, K., Ceh, M. and Stipec, K.: An integrated biophysical assessment of estuarine habitats in British Columbia to assist regional conservation planning, No. 476, Technical Report Series, 2007.

Schumacher, Brian A.: Methods for the Determination of Total Organic Carbon in Soils and Sediments, US Environmental Protection Agency Environmental Sciences Division- National Exposure Research Laboratory, Las Vegas, NV, USA, 2-11, 2002.

Weinmann, F.M., Boule, M., Brunner, K., Malek, J., Yoshino V.: Wetland Plants of the Pacific Northwest, US Army Corps of Engineers, Seattle, WA, USA, 1984. 